\title{
A tripartite survey of hyperparasitic fungi associated with ectoparasitic flies on bats (Mammalia: Chiroptera) in a neotropical cloud forest in Panama
}

Melissa J. Walker ${ }^{1,2, a}$, Annabel Dorrestein ${ }^{2,3, a}$, Jasmin J. Camacho ${ }^{4}$, Lauren A. Meckler ${ }^{5}$, Kirk A. Silas ${ }^{6}$, Thomas Hiller ${ }^{7}$, and Danny Haelewaters ${ }^{4,8,9,{ }^{*}}$

${ }^{1}$ Department of Ecology, Environment and Evolution, La Trobe Institute for Molecular Science Bundoora, Victoria 3083, Australia

${ }^{2}$ Current address: Hawkesbury Institute for the Environment, Western Sydney University, Science Road, Richmond, New South Wales 2753, Australia

3 Department of Animal Ecology, Utrecht University, Padualaan 8, 3584 CH Utrecht, The Netherlands

${ }^{4}$ Department of Organismic and Evolutionary Biology, Harvard University, 26 Oxford Street, Cambridge, Massachusetts 02138, USA

${ }^{5}$ Department of Psychological and Brain Sciences, University of Delaware, 105 The Green, Newark, Delaware 19716, USA

${ }^{6}$ Painted Sky Road, Reading, Pennsylvania 19606, USA

${ }^{7}$ Institute of Evolutionary Ecology and Conservation Genomics, University of Ulm, Albert-Einstein Allee 11, 89081 Ulm, Germany

8 Smithsonian Tropical Research Institute, Apartado Postal 0843-03092, Balboa, Panama

${ }^{9}$ Herbario UCH, Universidad Autónoma de Chiriquí, Apartado Postal 0427, David, Panama

Received 17 November 2017, Accepted 5 March 2018, Published online 10 April 2018

\begin{abstract}
The Darién province in eastern Panama is one of the most unexplored and biodiverse regions in the world. The Chucantí Nature Reserve, in Serranía de Majé, consists of a diverse tropical cloud forest ecosystem. The aim of this research was to explore and study host associations of a tripartite system of bats, ectoparasitic flies on bats (Diptera, Streblidae), and ectoparasitic fungi (Ascomycota, Laboulbeniales) that use bat flies as hosts. We captured bats at Chucantí, screened each bat for presence of bat flies, and screened collected bat flies for presence of Laboulbeniales. We mistnetted for 68 mistnet hours and captured 227 bats representing 17 species. We captured Micronycteris schmidtorum, a species previously unreported in Darién. In addition, we encountered the rarely collected Platyrrhinus dorsalis, representing the westernmost report for this species. Of all captured bats, 148 carried bat flies (65\%). The number of sampled bat flies was 437, representing 16 species. One species represents a new country record (Trichobius anducei) and five species represent first reports for Darién (Basilia anceps, Anatrichobius scorzai, Nycterophilia parnelli, T. johnsonae, T. parasiticus). All 74 bat fly species currently reported in Panama are presented in tabulated form. Of all screened bat flies, 30 bore Laboulbeniales fungi (7\%). Based on both morphology and large ribosomal subunit (LSU) sequence data, we delimited 7 species of Laboulbeniales: Gloeandromyces nycteribiidarum (newly reported for Panama), G. pageanus, G. streblae, Nycteromyces streblidinus, and 3 undescribed species. Of the 30 infected flies, 21 were Trichobius joblingi. This species was the only host on which we observed double infections of Laboulbeniales.
\end{abstract}

Keywords: Bat flies, Diptera, Ectoparasites, Hyperparasites, Laboulbeniales, Sequence-based identification of fungi

Résumé - Étude tripartite des champignons hyperparasites associés aux mouches ectoparasites des chauves-souris (Mammalia, Chiroptera) dans une forêt néotropicale au Panama. La province de Darién dans l'est du Panama est l'une des régions les plus inexplorées et les plus riches en biodiversité au monde. La réserve naturelle du Chucantí, à Serranía de Majé, est constituée d'un écosystème forestier tropical varié. Le but de cette recherche était d'explorer et d'étudier les associations hôtes d'un système tripartite de chauves-souris, de mouches ectoparasites sur chauves-souris (Diptera, Streblidae) et de

\footnotetext{
*Corresponding author: dhaelewaters@fas .harvard.edu
}

${ }^{a}$ These authors contributed equally to the manuscript 
champignons ectoparasites (Ascomycota, Laboulbeniales) utilisant des diptères de chauves-souris comme hôtes. Nous avons capturé des chauves-souris à Chucantí, criblé chaque chauve-souris pour la présence de diptères, et criblé les diptères recueillis pour la présence de Laboulbeniales. Nous avons utilisé des filets japonais pendant 68 heures et avons capturé 227 chauves-souris représentant 17 espèces. Nous avons capturé Micronycteris schmidtorum, une espèce précédemment non rapportée de Darién. En outre, nous avons rencontré l'espèce rarement collectée Platyrrhinus dorsalis, ce qui représente la mention la plus occidentale de cette espèce. De toutes les chauves-souris capturées, 148 portaient des diptères (65\%). Le nombre de diptères échantillonnés était de 437, représentant 16 espèces. Une espèce représente une nouvelle mention pour ce pays (Trichobius anducei) et cinq espèces représentent les premières mentions pour Darién (Basilia anceps, Anatrichobius scorzai, Nycterophilia parnelli, T. johnsonae, T. parasiticus). Les 74 espèces de diptères de chauves-souris actuellement signalées au Panama sont présentées sous forme de tableau. Parmi tous les diptères examinés, 30 portaient des champignons Laboulbeniales (7\%). Sur la base de la morphologie et des données des séquences d'ADNr LSU, nous avons délimité 7 espèces de Laboulbeniales : Gloeandromyces nycteribiidarum (nouvelle mention pour Panama), G. pageanus, G. streblae, Nycteromyces streblidinus et 3 espèces non décrites. Sur les 30 mouches infectées, 21 étaient des Trichobius joblingi. Cette espèce est le seul hôte sur lequel nous avons observé des doubles infections de Laboulbeniales.

\section{Introduction}

Panamanian forests are under major risk of deforestation, threatening the associated biodiversity. The 2015 Global Forest Resources Assessment reports that $62.1 \%$ of Panama is forested; however, there was an annual change rate of $-0.4 \%$ between 1990 and 2015 [23]. Recent efforts by various independent bodies and organizations have focused on securing existing forests, reforesting farm lands, and reporting on unidentified and known species endemic to the region. In recent years, many new species of plants, animals, and fungi have been reported in Panamanian forests. A Google Scholar search (on September 23, 2017) using the keywords "new species" and "Panama" resulted in 1,740 hits since 2017 alone. This collaborative management has benefited Panama's native flora and fauna, while promoting the importance of rainforest conservation $[61,81,82,96,97]$. Although research efforts are steadfast, difficult terrain and political strife leaves many Panamanian locations isolated and difficult to explore.

One such location is the Darién province, in eastern Panama. Darién, host to the Darién National Park, is one of the most pristine habitats in Central America, and one of the most endemically biodiverse zones in the world. Dividing the Panamá and Darién provinces is the Serranía de Majé, a $60 \mathrm{~km}$ long, 404 ha mountain range with elevations from 600 to $1480 \mathrm{~m}$ a.s.l. [2,71]. The summit of Serranía de Majé is Cerro Chucantí, a diverse tropical cloud forest ecosystem [71] and host to the Chucantí Nature Reserve. However, the rough terrain, proximity to Colombian border, and isolation of Cerro Chucantí has thus far resulted in many species going undocumented.

Prior to private purchase, parts of Chucantí Nature Reserve (hereafter: Chucantí) were subject to logging, established as farmland, and severely under threat by agricultural and livestock activities $[17,48,55]$. While this threat is still evident in regions of the Serranía de Majé, much of Chucantí is recovering. This constructive reestablishment of the natural ecosystem, in conjunction with researchers obtaining supported access to the mountain, has spurred greater insight into the environment of this area. Accordingly, we documented bat species richness and abundance at three altitudes in Chucantí. We screened all captured bats for the presence of bat flies, which in turn were screened for the presence of Laboulbeniales fungi, with the aim of reporting biodiversity at different trophic levels (host-parasiteparasite) and studying host associations. Below, we briefly introduce the three levels of this hyperparasitic study system.

\section{Bats (Mammalia: Chiroptera)}

Bats are the only mammals capable of sustained flight. They use echolocation and have a wide assortment of food sources, thereby providing important ecosystem services like insect predation and seed dispersal [54]. The New World leaf-nosed bats (family Phyllostomidae) are the most morphologically and ecologically diverse of all bats. They have evolved extraordinarily diverse faces, skulls, and teeth, adapted to many different food types, including insects, other vertebrates, blood, fruit, and nectar [26]. Bats also differ greatly in their roosting habits; roosts vary from more permanent and enclosed structures (caves, rock crevices, mines) to ephemeral and exposed structures (leaf tents, plant foliage) [53].

There are around 1,200 species of bats worldwide [9]. In Panama, a total of 118 bat species are documented, therefore representing the most diverse mammal group in the country [78]. Although these species reports are numerous, many of the results come from lowland research, leaving many highland Panamanian regions without mammal inventories; Chucantí is one of them [43,77]. Given the isolation of Chucantí, it is not surprising that only limited biodiversity reports from this area are available, and none dealing with bats. With a variety of 
morphological differences, dietary differentiation, and ecological requirements, bats are assumed to cohabitate and exploit the ecological diversity of the Chucantí cloud forests.

\section{Bat flies (Diptera: Hippoboscoidea: Streblidae and Nycteribiidae)}

Bat flies are obligate blood-feeding ectoparasites of bats. They are generally assigned to two families: the monophyletic Nycteribiidae with a mainly Palaearctic distribution, and the paraphyletic Streblidae that are most diverse in the Neotropics [18]. On their bat host, they show preferences for certain body areas like the furry body or the wing membranes [84]. Bat flies spend most of their life on their hosts, and female bat flies only leave to deposit 3rd instar larvae in the bat roost, which immediately pupate [16].

Bat flies are highly host specific $[13,15]$. Large-scale bat surveys in the field have led to this understanding. For example, in Paraguay, 2,893 captured bats yielded 2,467 bat flies, of which $87.1 \%$ were highly host specific. Bat social structure and bat roosting behavior are important contributors to population dynamics of these parasites [74]. The majority of the neotropical Streblidae are parasites of Phyllostomidae, the highly diverse leaf-nosed bats $[15,39,93,94]$. Currently, a total of 73 bat fly species are known to occur in Panama $[27,39,94]$. Of these, a majority belong to Streblidae (66 species).

As parasites comprise a crucial part of bat ecology [95], sampling bat flies together with biological data of the host individuals can provide valuable information on animal health [56]. Bat flies, too, can serve as hosts to smaller biota, such as the enigmatic, microscopic Laboulbeniales fungi.

\section{Laboulbeniales (Fungi: Ascomycota: Laboulbeniomycetes)}

The order Laboulbeniales consists of microscopic ectosymbionts of myriad arthropods. As an exception among related groups of fungi, they do not grow hyphae but form a "reduced hyphal system" (thallus, plural thalli) formed by a predetermined number of mitotic divisions. A thallus typically consists of 3 main parts: a receptacle, which attaches to the host; a perithecium, the sporeforming structure, or multiple perithecia; and appendages with antheridia that produce spermatia. Laboulbeniales are usually host specific, often with a one-on-one relationship. The inverse can also be true, when one species or morphologically similar species of Laboulbeniales are associated with completely unrelated hosts. In this case, phylogenetically unrelated hosts inhabit the same microhabitat, providing opportunities for fungal ectoparasites to transmit to atypical hosts [sensu 12]. As different species of bat flies can occur on a single bat, the bat as a whole serves as a microhabitat, and thus we hypothesize that at least sometimes transmission between typical and atypical bat fly hosts will take place.
About $80 \%$ of described species of Laboulbeniales are found on Coleoptera, and only $10 \%$ on Diptera [92]. Laboulbeniales associated with flies belong to 8 genera, 3 of those are exclusive to bat flies: Arthrorhynchus, Gloeandromyces, and Nycteromyces [41]. Only the genera Gloeandromyces and Nycteromyces occur on neotropical bat flies. Thus far in Panama, only 3 species of Laboulbeniales have been reported on bat flies: Gloeandromyces pageanus, which was described from bat flies collected in Gamboa in the Canal Zone (Colón Province), G. streblae, and Nycteromyces streblidinus [42].

\section{Material and Methods \\ Ethics and permits}

All capture and sampling procedures were licensed and approved by the Smithsonian Tropical Research Institute (IACUC protocol: 2017-0102-2020-A5) and the Government of Panama (Ministerio de Ambiente de Panamá: SE/ AH-2-16, SC/AH-1-17).

\section{Field sites}

We visited Chucantí $\left(8.8046^{\circ} \mathrm{N}, 78.4595^{\circ} \mathrm{W}\right)$ from June 17 to 25,2017 (rainy season). Chucantí is a large area of submontane forest surrounded by livestock pastures although still in contact with original vegetation. The reserve has premontane wet forests and tropical moist forests [sensu 45]. Within these forest types, secondary forest succession describes three of our field sites, defined by the degree of disturbance of the area. We visited one field site, an undisturbed primary forest, comparatively. Bats were captured at these four field sites at Chucantí over seven nights (Figure 1). (1) "Helipad" was a heavily disturbed area, approximately $25 \mathrm{~m}$ perpendicular to the Loop Trail, which circles around the research station towards the north. The site was felled during the time of our visit. As a result, the area was cleared of most vegetation, except for low grasses and some dispersed trees, and designated as early secondary succession. Close-by, towards the south of the field site, was an open field with high grasses. (2) "Waterfall" describes the field site with old-growth broadleaf characteristics presenting proliferation of secondary vegetation and loss of arboreal cover, adjacent to a river and waterfall, with flyways heavily disturbed by horses, construction workers, and staff of the nature reserve; young secondary succession. (3) "Potrerito", located along a trail with the same name that runs from the research station to the Camp Site, was situated in an old-growth, broadleaf forest close to a river, which opened towards a recovering livestock pasture with tall grasses, frequented by horses; middle-aged secondary succession. (4) "Camp Site" was located on the trail towards the summit of Chucantí, with many palm trees, oaks, fig trees, epiphytes, and bromeliads growing densely on tree branches and stems, and a few tall, giant trees. This site, to our knowledge, has not been used as agricultural land, and is the least disturbed of our sites, thus classified as primary forest. 


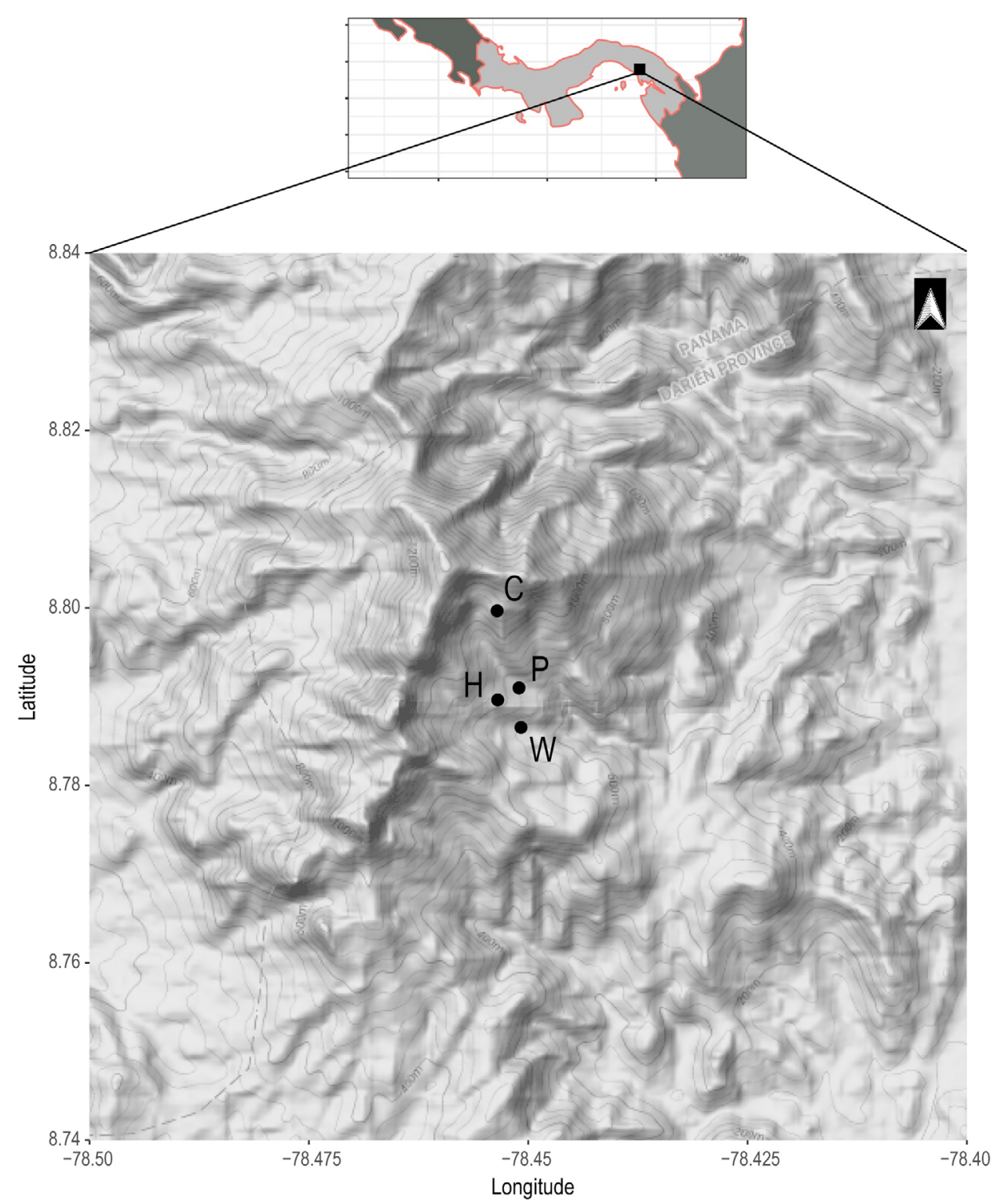

Figure 1. Geographical map of the studied area, with its location in Panama. The four sampled field sites at Chucantí Nature Reserve are indicated as follows: $\mathrm{C}=$ Camp Site, $\mathrm{H}=$ Helipad, $\mathrm{P}=$ Potrerito, and $\mathrm{W}=$ Waterfall.

\section{Capture of bats and collection of bat flies}

Bats were captured using three to four 6 -m ground level mistnets (36-mm mesh, 4 shelves, Avinet, Portland, ME, USA). Mistnets were positioned over existing trails, which we assessed to be used by bats as flight paths [73], including streams and close to water bodies. The nets were usually open from sunset to around $11 \mathrm{pm}$ and examined every $10 \mathrm{~min}$. Bats were disentangled quickly and kept in clean, soft cotton bags until processing. Bats were released at the vicinity of the capture site immediately after processing. Most nectarivorous and frugivorous bats were fed with sugar water prior to release.

Captured bats were identified on site using dichotomous keys [44,87]. For each bat, the following characteristics were noted: species, sex, age (juvenile, subadult, adult), reproductive status (pregnant, lactating, post- lactating, scrotal, non-reproductive), forearm length (in mm), body mass (ing), and whether bat flies were collected. We also noted whether a wing punch and/or photographs were taken. When abnormalities such as abscesses, wounds, or broken fingers or teeth were observed, comments were added for each respective bat. Bat taxonomy follows Simmons [79].

In order to remove ectoparasitic bat flies, we used a paintbrush to cover the flies on the bat with $96 \%$ ethanol. Subsequently, the bat flies were taken using forceps. Some bat flies were collected using the forceps only or by hand. Two types of forceps were used: rigid Swiss Style Forceps \#5 with superfine tip (BioQuip \#4535, Rancho Dominguez, CA, USA) and Featherweight Forceps with narrow tip (BioQuip \#4748). Preservation and long-term storage of bat flies was in $96 \%$ ethanol in separate vials (one vial per bat host). Identification of bat flies to species 
level was based on published keys [29-37,93,94] and complementary publications $[14,66]$. Voucher specimens are deposited at the following locations: Museo de Peces de Agua e Invertebrados, David, Panamá (MUPADI) and Naturalis Biodiversity Center, Leiden, The Netherlands (RMNH).

\section{Collection and identification of Laboulbeniales}

Bat flies were examined under a Zeiss Stemi 508 stereomicroscope (Thornwood, New York) for the presence of Laboulbeniales thalli. Individual thalli were removed from the host at the point of attachment (foot or haustorium) using Minuten Pins (BioQuip \#1208SA, Rancho Dominguez, CA, USA) inserted onto wooden rods. We prepared microscope slides onto which thalli were mounted in Amann solution [6], with modifications. We placed a droplet of Hoyer's medium on the slide with the tip of a Minuten pin and deposited thalli in the droplet. The thalli were positioned onto the slide by placing them in a single row, each thallus in the tiniest droplet of Hoyer's medium. We then placed a droplet of the Amann solution on the cover slip, and dropped it (droplet facing down) sideways onto the Hoyer's medium. The cover slip was coated with transparent B-72 (Gaylord \#AB72, Syracuse, NY, USA) or nail varnish. We viewed mounted specimens at 400x to $1000 \mathrm{x}$ magnification for identification using those publications with descriptions and illustrations of Laboulbeniales occurring on bat flies $[42,85,86]$. Voucher slides are deposited at Farlow Herbarium (FH; Harvard University, Cambridge, MA, USA) and Herbario de la Universidad Autónoma de Chiriquí (UCH; David, Panamá).

\section{DNA extraction, amplification, phylogenetic analysis}

DNA was extracted from 1-4 Laboulbeniales thalli using a modified REPLI-g Single Cell Kit (Qiagen, Valencia, CA, USA) protocol [40]. Thalli were often manually cut in 2-3 parts (through the perithecium) using a \#10 surgical blade on disposable Bard-Parker handle (Aspen Surgical, Caledonia, MI, USA) to ensure successful lysis. For the purpose of this survey, we only amplified the nuclear large ribosomal subunit (LSU) using primers LR0R (5'-ACCCGCTGAACTTAAGC-3') and LR5 (5'ATCCTGAGGGAAACTTC-3'). PCR reactions consisted of $13.3 \mu \mathrm{L}$ of RedExtract Taq polymerase (SigmaAldrich, St. Louis, MO, USA), $2.5 \mu \mathrm{L}$ of each $10 \mu \mathrm{M}$ primer, $5.7 \mu \mathrm{L}$ of $\mathrm{H}_{2} \mathrm{O}$, and $1.0 \mu \mathrm{L}$ of template DNA. All amplifications were done using a 2720 Thermal Cycler (Applied Biosystems, Foster City, CA, USA) with initial denaturation at $94^{\circ} \mathrm{C}$ for 3:00 min; followed by 35 cycles of $94{ }^{\circ} \mathrm{C}$ for $1: 00 \mathrm{~min}, 50^{\circ} \mathrm{C}$ for $0: 45 \mathrm{~min}$, and $72^{\circ} \mathrm{C}$ for 1:30 min; and final extension at $72^{\circ} \mathrm{C}$ for 10:00 min. PCR products were purified using the QIAquick PCR Purification Kit (Qiagen) and subsequently sequenced at the Molecular Multi-User's Lab at the Naos Marine Laboratories (Smithsonian Tropical Research Institute, Panama). We prepared $10 \mu \mathrm{L}$ reactions with the same primers and $3.0 \mu \mathrm{L}$ of purified PCR product. The sequencing reactions were performed using the Big Dye ${ }^{\circledR}$ Terminator v3.1 Cycle Sequencing Kit (Life Technologies, Carlsbad, CA, USA). Generated sequences were assembled and edited in Sequencher 4.10.1 (Gene Codes Corporation, Ann Arbor, MI, USA). All sequences will be deposited in GenBank.

We constructed an LSU dataset of newly generated sequences and sequences downloaded from GenBank to assess species discrimination in the genus Gloeandromyces. Alignment of the LSU data matrix was done using Muscle v3.7 [21] on the Cipres Science Gateway, version 3.3 [65]. Maximum likelihood (ML) analysis was run using PAUP on XSEDE 4.0b [83], which is available on Cipres. The appropriate nucleotide substitution model was selected by considering the Akaike Information Criterion (AIC) in jModelTest 2.1 [11]. The general time reversible model (GTR) with estimation of invariant sites $(+\mathrm{I})$ and the assumption of a gamma distribution with six rate categories $(+\mathrm{G})$ gave the best scoring tree $(-\ln \mathrm{L}=$ 2867.4857). ML was inferred under this model and bootstrap (BS) values were calculated with 1000 replicates.

\section{Diversity analyses}

Further analyses of species diversity and network associations were done using the $\mathrm{R}$ language and environment for statistical computing [75]. A species accumulation curve was achieved using the 'vegan' package [70]. In addition, all collected data were combined by building a network of associations between bats, bat flies, and Laboulbeniales. This visualization was done with the help of the 'bipartite' package, using the plotweb function [19].

\section{Results}

\section{Bat species richness and dominance}

We mistnetted at 4 sites for 7 nights with a total netting effort of 68 mistnet hours (mnh), where $1 \mathrm{mnh}$ equals a single $6 \mathrm{~m}$-wide mistnet open for 1 hour (Table 1 ). We captured a total of 227 bats representing 17 species in 3 families (Table 2). All bat species captured at Chucantí are summarized in the Supplementary Material: Table S1, including the number of captured individuals, average forearm length (in mm), average body mass (ing), and photos taken in the field. The family Phyllostomidae was best represented with 14 species. The individuals of this family account for $95.15 \%$ of all captures. The most common species was Carollia perspicillata with $62.56 \%$ of all captures $(n=142)$, followed by Artibeus jamaicensis with $18.94 \%(n=43)$. Seven species were represented in our dataset by a single individual: Enchisthenes hartii, Lichonycteris obscura, Micronycteris microtis, $M$. schmidtorum, Platyrrhinus dorsalis, P. helleri, and Sturnira luisi.

The highest number of bat species and bat individuals were captured at Potrerito. The lowest number of individuals and species were captured at the Camp Site 
Table 1. Locality, coordinates and elevation (in $\mathrm{m}$ a.s.l.) of the mistnetting locations, together with the number of nights netted, the capturing effort (mnh), the number of bat species and bat individuals captured, and the number of bats $/ \mathrm{mnh}$.

\begin{tabular}{|c|c|c|c|c|c|c|c|}
\hline Field site & Coordinates & Elevation & Nights & $\begin{array}{l}\text { Capturing } \\
\text { effort (mnh) }\end{array}$ & $\begin{array}{l}\text { No. of } \\
\text { species }\end{array}$ & $\begin{array}{l}\text { No. of } \\
\text { individuals }\end{array}$ & $\begin{array}{l}\text { Bats/ } \\
\text { mnh }\end{array}$ \\
\hline Helipad & $\begin{array}{l}\text { N } 08^{\circ} 47.378^{\prime} \\
\text { W078 } 27.209^{\circ}\end{array}$ & 831 & 1 & 5.1 & 8 & 46 & 9 \\
\hline Waterfall & $\begin{array}{l}\text { N } 08^{\circ} 47.191^{\prime} \\
\text { W078 } 27.050^{\circ}\end{array}$ & 681 & 2 & 25.7 & 7 & 77 & 3 \\
\hline Portrerito & $\begin{array}{l}\text { N } 08^{\circ} 47.459^{\prime} \\
\text { W078 } 27.062^{\circ}\end{array}$ & 733 & 2 & 22.2 & 10 & 84 & 3.8 \\
\hline Camp Site & $\begin{array}{l}\text { N } 08^{\circ} 47.981^{\prime} \\
\text { W078 } 27.213^{\circ}\end{array}$ & 1141 & 2 & 15 & 6 & 20 & 1.3 \\
\hline Total & & & 7 & 68.0 & 17 & 227 & 5 \\
\hline
\end{tabular}

Table 2. The number of individuals captured per species at each locality. Species that have not been documented in Darién before are shown in bold [sensu 43,62]. Conservation status and current population trend are given for each species, according to the IUCN Red List. Handley Jr. [43] referred to the following species by different names, following contemporaneous taxonomy: Micronycteris microtis (as megalotis), Myotis riparius (as simus riparius), Platyrrhinus helleri (as Vampyrops helleri), Pteronotus gymnonotus (as suapurensis), and Sturnira luisi (as ludovici).

\begin{tabular}{|c|c|c|c|c|c|c|}
\hline Taxon & Helipad & Waterfall & Potrerito & Camp Site & Conservation & Population \\
\hline \multicolumn{7}{|l|}{ PHYLLOSTOMIDAE } \\
\hline Artibeus jamaicensis & 14 & 7 & 13 & 9 & Least Concern & Stable \\
\hline Artibeus lituratus & 0 & 7 & 3 & 1 & Least Concern & Stable \\
\hline Carollia brevicauda & 1 & 0 & 1 & 2 & Least Concern & Stable \\
\hline Carollia perspicillata & 24 & 59 & 57 & 2 & Least Concern & Stable \\
\hline Desmodus rotundus & 2 & 0 & 1 & 0 & Least Concern & Stable \\
\hline Enchisthenes hartii & 1 & 0 & 0 & 0 & Least Concern & Unknown \\
\hline Glossophaga commissarisi & 1 & 1 & 0 & 0 & Least Concern & Stable \\
\hline Lichonycteris obscura & 0 & 1 & 0 & 0 & Least Concern & Unknown \\
\hline Micronycteris microtis & 0 & 1 & 0 & 0 & Least Concern & Stable \\
\hline Micronycteris schmidtorum & 0 & 0 & 1 & 0 & Least Concern & Stable \\
\hline Platyrrhinus dorsalis & 0 & 0 & 0 & 1 & Least Concern & Unknown \\
\hline Platyrrhinus helleri & 0 & 0 & 1 & 0 & Least Concern & Stable \\
\hline Sturnira luisi & 1 & 0 & 0 & 0 & Least Concern & Unknown \\
\hline Trachops cirrhosus & 0 & 1 & 2 & 1 & Least Concern & Stable \\
\hline \multicolumn{7}{|l|}{ MORMOOPIDAE } \\
\hline Pteronotus gymnonotus & 0 & 0 & 2 & 0 & Least Concern & Stable \\
\hline Pteronotus parnellii & 2 & 0 & 2 & 0 & Least Concern & Stable \\
\hline \multicolumn{7}{|l|}{ VESPERTILIONIDAE } \\
\hline Myotis riparius & 0 & 0 & 1 & 4 & Least Concern & Stable \\
\hline Total & 46 & 77 & 84 & 20 & & \\
\hline
\end{tabular}

(Table 2). To assess the completeness of our survey, we plotted the cumulative number of species against the number of sites we surveyed. The data were randomized to exclude the effects of the order of the sites on the X-axis. The graph in Figure 2 does not reach an asymptote, indicating that our survey did not cover the bat diversity present in the area. The relative abundance distribution in Figure 3 visualizes the number of rare and abundant species. The abundance of most of the species we captured is relatively low, with only two species, A. jamaicensis and especially $C$. perspicillata, being highly abundant.

\section{Bat flies and Laboulbeniales}

Of the 227 bats we sampled at Chucantí, 148 carried bat flies (parasite prevalence of $65 \%$ ). A total of 437 bat flies were collected, representing 16 species, of which 15 belong to the family Streblidae and one (Basilia anceps) to the family Nycteribiidae. Details are presented in Table 3. The 6 specimens of Trichobius anducei, all collected from C. perspicillata bats, represent the first report of this species for Panama. Five species had not yet been reported from Darién. These are Anatrichobius scorzai, B. anceps, 


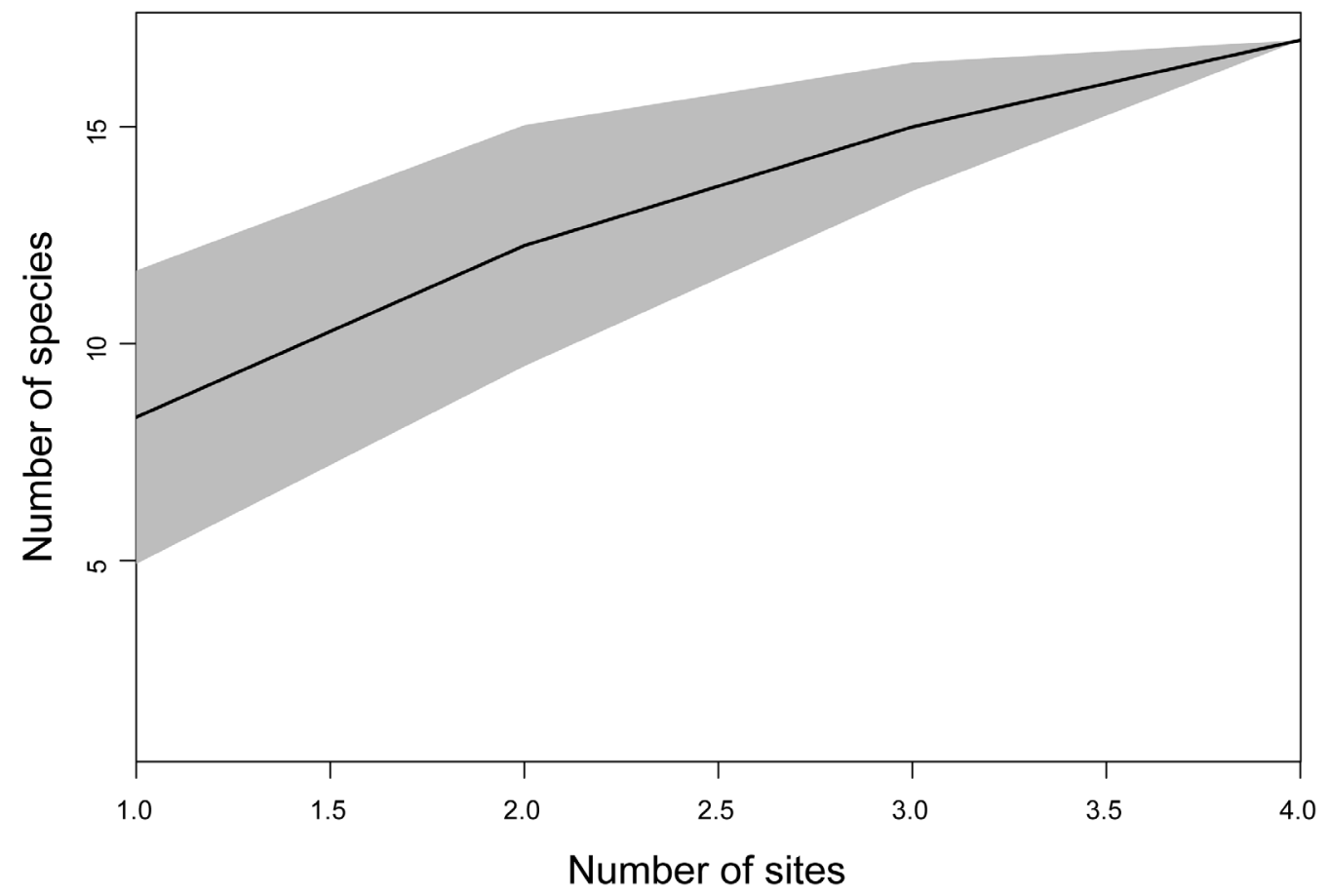

Figure 2. Species accumulation curve of the number of bat species captured at each site. The sites on the X-axis are randomized and cumulative. The area in grey represents the confidence interval.

Nycterophilia parnelli, Trichobius johnsonae, and $T$. parasiticus.

Trichobius joblingi was the most common species (58.58\%, $n=256)$, followed by Trichobius yunkeri $(11.21 \%, n=49)$, and Speiseria ambigua (10.30\%, $n=45)$. Six species were represented by a single individual: Megistopoda proxima, B. anceps, Nycterophilia parnelli, Paratrichobius longicrus, T. johnsonae, and T. parasiticus. Overall, the collected bat flies presented high host specificity with 17 of 21 associations and $97.5 \%$ of all individual bat flies counted as primary associations; only occasionally bat flies were found on non-primary hosts (Figure 4; Table 3). Two bat fly species, Aspidoptera phyllostomatis and Megistopoda aranea, appeared to be sharing two bat host species as both were commonly collected from the two large Artibeus species captured in this study.

We found infection with Laboulbeniales on 30 of 437 bat flies (6.86\%). All Laboulbeniales belonged to the genera Gloeandromyces and Nycteromyces. We found all 4 described species from neotropical bat flies: G. nycteribiidarum, G. pageanus, G. streblae, and N. streblidinus. In addition, based on both morphological characters and molecular data, we discovered 3 undescribed species in the genus Gloeandromyces. All species of Laboulbeniales encountered in Chucantí and their hosts are given in Table 4. Data on the prevalence of Laboulbeniales infection among bat fly species are presented in Table 5 . The most frequently encountered species was $G$. streblae (on 12 bat flies of 3 species), followed by N. streblidinus (on 9 bat flies of 2 species). The thalli removed from five bat flies (1 Speiseria ambigua, 4 T. joblingi) were too young for secure identification to species level or even genus level.
Trichobius joblingi was most often infected with Laboulbeniales; of the 30 bat flies infected with Laboulbeniales, 21 were $T$. joblingi. This bat fly species also bore most diversity of Laboulbeniales. We found 5 species on this bat fly: $G$. streblae, 3 undescribed species of Gloeandromyces, and N. streblidinus. Finally, we observed double infections of Laboulbeniales, but only on $T$. joblingi bat flies. The following combinations of fungi occur together on a single host specimen: G. streblae with G. sp. nov. 1, G. streblae with N. streblidinus, and G. sp. nov. 1 with $N$. streblidinus. Gloeandromyces sp. nov. 1 was only observed at the base of the right wing, while the other two species occur on different positions of the host's body.

\section{Molecular work}

Our LSU dataset comprised 961 characters, of which 711 were constant and 231 were parsimony-informative. A total of 18 sequences were included in the dataset, of which 11 were newly generated during the course of this study, complemented by 7 sequences that we retrieved from GenBank: Herpomyces chaetophilus (2 isolates), $H$. periplanetae (3) as outgroup taxa; Stigmatomyces protrudens (1) (associated with Diptera: Ephydridae); $G$. nycteribiidarum (1), G. pageanus (3), G. sp. nov. 1 (3), G. sp. nov. 3 (2), and G. streblae (3). The genus Gloeandromyces was strongly supported in our ML phylogenetic reconstruction (Figure 5). All five species of the genus were supported by $\mathrm{BS} \geq 75$, usually even by $\mathrm{BS} \geq 90$.

Gloeandromyces sp. nov. 2 was found on a single $T$. joblingi bat fly only, only three thalli were present. We tried a DNA extraction using a single thallus as starting 


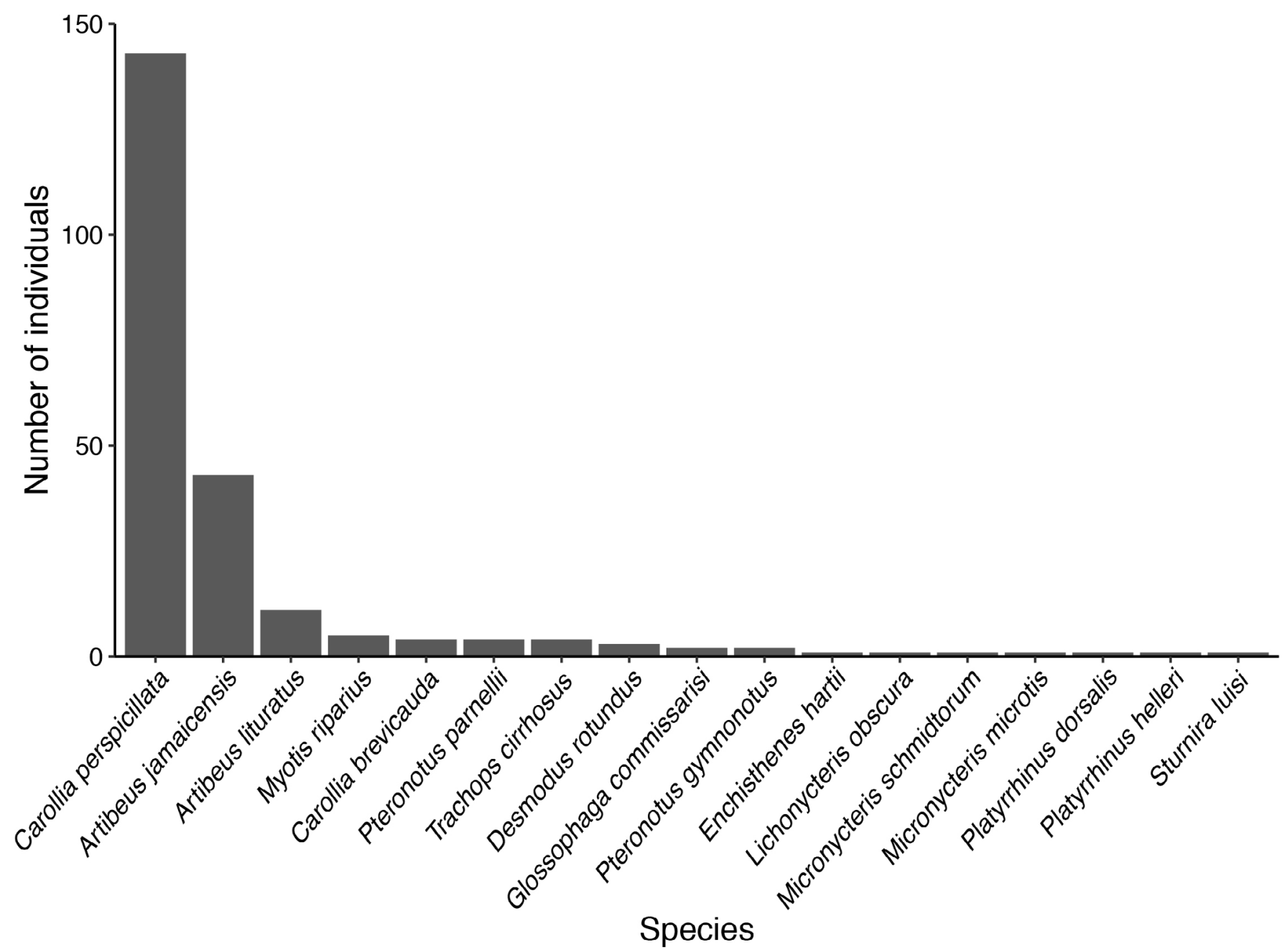

Figure 3. Number of individuals per bat species captured in Chucantí.

material, which was unsuccessful. However, based on morphological characters, we assume that these thalli represent an undescribed species. It is easily recognized by the perithecial neck carrying a large preapical projection, and a sigmoidal habitus. The same species was also collected in 2016 in Gamboa, Panama, again on a single $T$. joblingi bat fly (D. Haelewaters, unpublished data). No DNA extraction was attempted at that time.

\section{Discussion}

\section{Bat ectoparasites and hyperparasites from Chucantí}

Our species list of ectoparasitic bat flies includes 16 species of which one, T. anducei, was previously unreported for Panama. With this report, the number of Panamanian bat fly species rises to 74 (Table 6). Trichobius anducei was described relatively recently [36] from C. perspicillata in Venezuela and has since been reported in Brazil [58] and Ecuador [80]. Trichobius anducei has been confused with $T$. dugesioides in previous studies; for this reason, Guerrero [36] presented distinct morphological characteristics for alcohol-preserved speci- mens, such as differences in setation of the 9 th tergite in male bat flies, on which we based our identifications (see Figure 6). For Belize, ter Hofstede et al. [84] reported an unidentified bat fly from $C$. perspicillata and $C$. brevicauda, which the authors recognized to be similar to $T$. dugesioides and T. anducei and, together with unpublished records from Panama and Costa Rica (T. Hiller, unpublished data), might confirm the presence of $T$. anduce $i$ in Central America. Five bat fly species collected at Chucantí represent first reports for Darién. These are $B$. anceps (Nycteribiidae), A. scorzai, N. parnelli, T. johnsonae, and $T$. parasiticus (Streblidae). We are confident that more bat fly species are present at Chucantí for two reasons: the sample size for some bat species was small and certain bat host species known to occur in Darién [94] were not captured. Nevertheless, our new reports for Panama and the Darién province highlight the need for more taxonomical and ecological studies focusing on host-parasite interactions.

The reported bat fly-bat interactions were highly specific; $97.5 \%$ off all bat fly individuals collected were associated with their primary host, comparable to other studies from Panama, Venezuela, and Paraguay 
Table 3. List of bat fly species collected during this study, with indication of their bat host species and number of infected bats, the number of collected bat flies $(\mathrm{N})$, and the specificity index $(\mathrm{SI})=$ the percentage of total bat flies of a single species found on one host.

\begin{tabular}{|c|c|c|c|}
\hline Bat host species $(\#)$ & Bat fly species & $\mathrm{N}$ & SI \\
\hline \multirow[t]{3}{*}{ Artibeus jamaicensis (43) } & Megistopoda aranea & 14 & 0.67 \\
\hline & Paratrichobius longicrus & 1 & 1.00 \\
\hline & Aspidoptera phyllostomatis & 8 & 0.89 \\
\hline \multirow[t]{2}{*}{ Artibeus lituratus (11) } & Megistopoda aranea & 6 & 0.29 \\
\hline & Aspidoptera phyllostomatis & 1 & 0.11 \\
\hline Carollia brevicauda (4) & Trichobius joblingi ${ }^{*}$ & 7 & 0.03 \\
\hline \multirow[t]{4}{*}{ Carollia perspicillata (142) } & Speiseria ambigua & 43 & 0.96 \\
\hline & Strebla guajiro & 22 & 1.00 \\
\hline & Trichobius joblingi & 248 & 0.97 \\
\hline & Trichobius anducei & 6 & 1.00 \\
\hline Desmodus rotundus (1) & Trichobius parasiticus & 1 & 1.00 \\
\hline Micronycteris schmidtorum (1) & Trichobius joblingi* & 1 & 0.00 \\
\hline \multirow[t]{2}{*}{ Myotis riparius (5) } & Basilia anceps & 1 & 1.00 \\
\hline & Anatrichobius scorzai & 3 & 1.00 \\
\hline Pteronotus gymnonotus (1) & Trichobius johnsonae & 1 & 1.00 \\
\hline \multirow[t]{3}{*}{ Pteronotus parnellii (4) } & Nycterophilia parnelli & 1 & 1.00 \\
\hline & Trichobius yunkeri & 49 & 1.00 \\
\hline & Megistopoda aranea ${ }^{*}$ & 1 & 0.05 \\
\hline Sturnira luisi (1) & Megistopoda proxima & 1 & 1.00 \\
\hline \multirow[t]{2}{*}{ Trachops cirrhosus (4) } & Speiseria ambigua* & 2 & 0.04 \\
\hline & Trichobius dugesioides & 20 & 1.00 \\
\hline
\end{tabular}

* $=$ non-primary association.

$[15,93,94]$. The occurrence of single bat fly individuals on non-primary hosts is most likely due to contamination in the net or while handling the bat [13]. In most of these cases, the specific parasite is very abundant on their primary host, which was captured together with the nonprimary host during the same sampling night. Due to the high capture numbers at two sampling sites, we sometimes placed two individuals of the same bat species (mostly Carollia) in a single cotton bag. However, we did not focus on parasite prevalences of bat flies on their bat hosts, so even when cross-contamination occurred in the bag, this had no influence on our host-association data. In cases of re-using cotton bags before washing them, we made sure to flip them inside-out first. Taking into account that bat flies have a limited lifespan when they are separated from their bat hosts ( 12 hours [72]), cross-contamination between sampling nights is highly unlikely.

The most common bat fly collected in this study was $T$. joblingi. Its primary host $C$. perspicillata was abundant at every capture site. The single individual collected from $M$. schmidtorum is therefore most likely an accidental occurrence. The same applies for a single individual of $M$. aranea from $P$. parnellii and the two individuals of $S$. ambigua, a bat fly which is easily distressed and flies off [15], from Trachops cirrhosus. The specificity index of $T$. joblingi on Carollia brevicauda is very low (0.03), indicating a non-primary host association, but the low number of $C$. brevicauda captured as well as literature records suggest that this is a primary host association
$[93,94]$. The same might also be true for the parasite associations of the two large-sized Artibeus species, A. jamaicensis and $A$. lituratus, both sharing $M$. aranea and A. phyllostomatis, which are typically associated with $A$. jamaicensis. The single individual of Paratrichobius longicrus, a typical parasite of A. lituratus, was collected from A. jamaicensis. These host-parasite relationships were not as expected but are also previously reported for Panama by Wenzel et al. [94]. A probable explanation might be the uncertain status of $A$. intermedius and the overlap of morphological characteristics given in the literature, which often made definitive species identification in the field difficult. The combination of unclear species limits and possible contaminations during sampling most likely explains this inconsistent host-parasite relationship.

Bat flies are the most conspicuous and therefore best investigated group of bat-associated ectoparasites in Panama. However, there are over 50 species of other ectoparasitic arthropods reported from Panama, all identified based on morphological characteristics alone [94]. This list includes mites in the families Dermanyssidae (10 species), Spinturnicidae (16), and Trombiculidae (22); ticks (8); fleas (4); and true bugs (2). Given the fact that this study [94] was done over 50 years ago, more species - in particular for the mites - are expected in future studies focusing on these groups, especially when incorporating contemporary molecular phylogenetic techniques. 


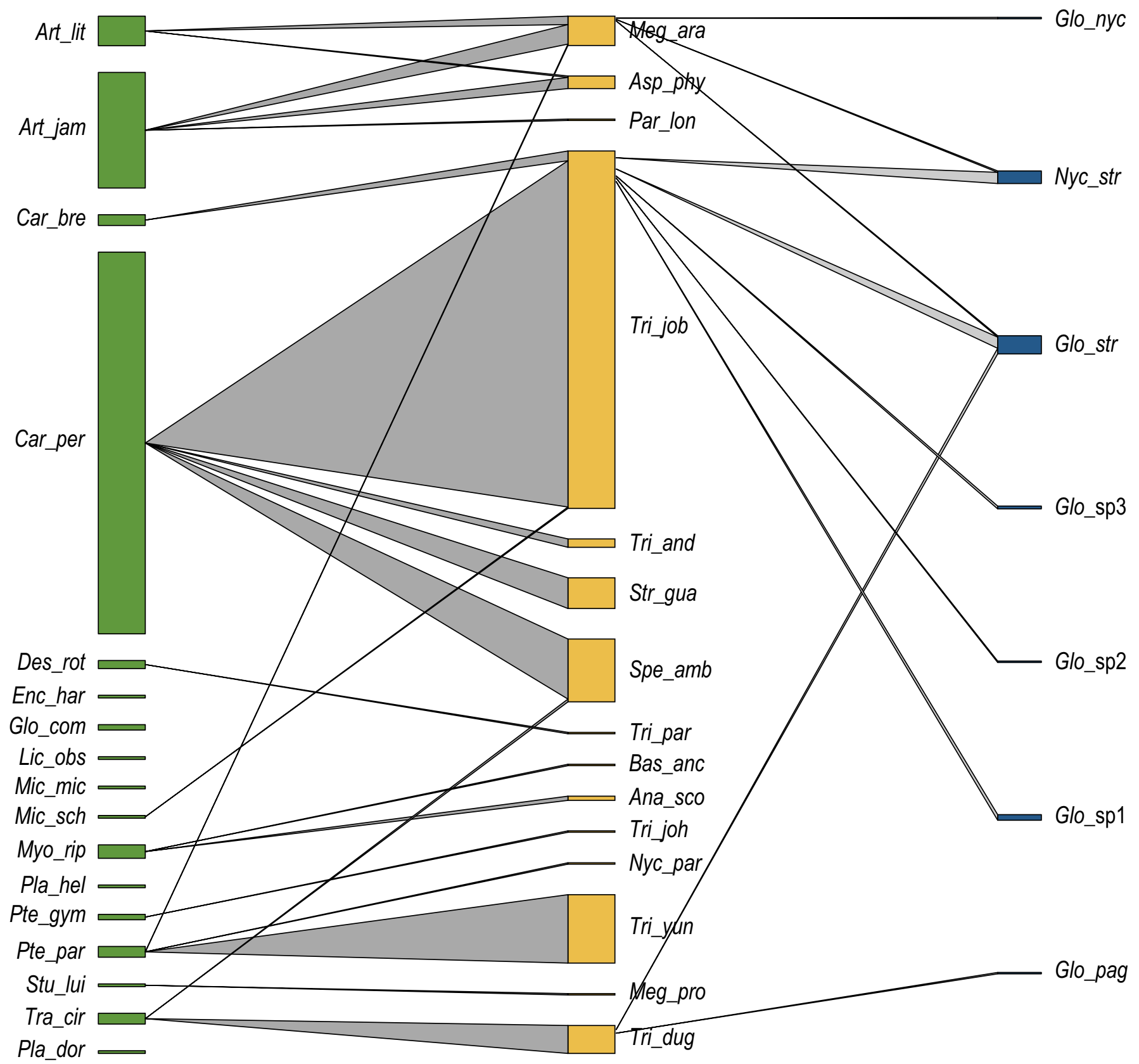

Figure 4. Interaction web between bat species (left), bat fly species (middle), and Laboulbeniales species (right) from Chucantí. The width of bars in each network level is proportional to the number of individuals.

The thalli of Laboulbeniales encountered on bat flies from Chucantí represented 7 species. Of these, $G$. nycteribiidarum represents a new country record for Panama. Gloeandromyces pageanus, G. streblae, and N. streblidinus are new reports for Darién. In addition, we discovered 3 undescribed species in the genus Gloeandromyces. Laboulbeniales of bat flies are rarely reported. For example, G. nycteribiidarum has only been previously reported in Grenada [86] and Costa Rica [42]. In fact, the study of Laboulbeniales fungi associated with bat flies has been largely neglected for the past 80 years. Until the records presented here and by Haelewaters et al. [42], only the type collections were known for $G$. nycteribiidarum, $G$. streblae, and $N$. streblidinus. The discovery of 3 new species in a limited study area only hints at the true diversity of Laboulbeniales on neotropical bat flies. Laboulbeniales on bat flies from temperate regions, on the other hand, are apparently rather species-poor $[7,41]$.

\section{Sequence-based identification of Laboulbeniales ectoparasitic fungi}

Using LSU sequence data for species delimitation is a new development in Laboulbeniales taxonomy. To date, species have been delimited by the internal transcribed spacer region (ITS, consisting of ITS1-5.8S-ITS2) of the 
Table 4. The species of Laboulbeniales found in Chucantí, with their bat fly hosts and the bat species from which the bat fly hosts were collected. Between parentheses is the number of bat flies observed with thalli of a given species, and the number of bat hosts if infected bat flies originated from different bat species. On some bat flies, only immature thalli were found, which were impossible to identify to species level (on 4 flies) or even genus level (on a single fly). These identifications are presented as sp. indet.

\begin{tabular}{lll}
\hline Laboulbeniales species & Bat fly host species & Bat host species \\
\hline Gloeandromyces nycteribiidarum & Megistopoda aranea $(1)$ & Artibeus jamaicensis \\
Gloeandromyces pageanus & Trichobius dugesioides $(1)$ & Trachops cirrhosus \\
Gloeandromyces streblae & Megistopoda aranea $(1)$ & Artibeus jamaicensis \\
& Trichobius dugesioides $(4)$ & Trachops cirrhosus \\
& Trichobius joblingi $(8)$ & Carollia perspicillata \\
Gloeandromyces sp. nov. 1 & Trichobius joblingi $(4)$ & Carollia brevicauda $(1)$ \\
& & Carollia perspicillata $(3)$ \\
Gloeandromyces sp. nov. 2 & Trichobius joblingi $(1)$ & Carollia perspicillata \\
Gloeandromyces sp. nov. 3 & Trichobius joblingi $(2)$ & Carollia perspicillata \\
Gloeandromyces sp. indet. & Trichobius joblingi $(3)$ & Carollia perspicillata \\
Nycteromyces streblidinus & Speiseria ambigua $(1)$ & Carollia perspicillata \\
& Megistopoda aranea $(1)$ & Artibeus jamaicensis \\
Laboulbeniales sp. indet. & Trichobius joblingi $(8)$ & Carollia brevicauda $(1)$ \\
& & Carollia perspicillata $(7)$ \\
\end{tabular}

ribosomal DNA. However, in general the ITS region is hard to amplify for species of Laboulbeniales, even with recommended primers. Thus, whenever species of Laboulbeniales in genera without sequence data are considered for molecular work, most of the "general" ITS primers may not work. The reason is that both the ITS1 and ITS2 spacers are rapidly evolving regions [69], with primer mismatches as a result. We have no idea of the extent of variability in the ITS rDNA in genera for which no ITS sequences exist to date, such as Gloeandromyces and Nycteromyces.

However, the LSU region is much easier to amplify in Laboulbeniales with commonly used primers such as LR0R/LR5. Based on the evaluation of LSU sequence data in the genera Herpomyces [40] and Hesperomyces, we found that this marker has high discriminating power, comparable to the ITS (D. Haelewaters, unpublished data). Those two factors combined (easy amplification and high identification power) make the LSU region a favorable marker over the ITS rDNA. As a result, we focused on generating LSU sequences for this study. We were able to generate sequences for all species of Gloeandromyces but one; we found strong support for all 3 described species and 2 undescribed ones. (Support for the third undescribed species comes from morphological study.)

\section{Bat species richness and abundance}

Several published studies have focused on bat diversity in Panama $[3,43,51,62,77]$, but only a few reports are available for bats captured in Darién [43,62], and no studies are available from Chucantí. After an assessment of the literature, we found that all bat species from Chucantí had been reported before in Panama and, with the exception of M. schmidtorum, also in Darién. In fact, $M$. schmidtorum was previously only reported in the province of Los Santos [43]. The specimen of $P$. dorsalis from Chucantí represents the westernmost report for this species, and only the second from Panama. Previous records were from Cerro Mali in Darién (as Vampyrops aquilus), Colombia, Ecuador, and (northern) Venezuela [88].

Species richness in Chucantí was highest in the family Phyllostomidae. The two most abundant species accounted for $81.5 \%$ of total captures (C. perspicillata $62.56 \%$, A. jamaicensis $18.94 \%$ ). Based on surveys in Cerro Batipa (Chiriquí), Samudio Jr. [77] also found that the family Phyllostomidae was most diverse. However, in his field site at 1000-1200 m a.s.l. (comparable to our sites), the 6 most abundant species were (in decreasing order): Artibeus toltecus, Sturnira mordax, Platyrrhinus vittatus, Sturnira hondurensis, A. lituratus, and $C$. brevicauda. Studies in central Panamanian lowlands, mainland, and island captures around the Barro Colorado Nature Monument, also identified A. jamaicensis and $A$. lituratus as the predominate species [51]. In central Panamanian coastlands, at $850 \mathrm{~m}$ in Capira, Araúz [3] found 22 species, 19 of which were Phyllostomidae. Abundant species included A. jamaicensis, A. lituratus and $C$. perspicillata. This indicates that our findings on dominant families and species are consistent with previous studies conducted in other parts of Panama.

We found one individual of the bat S. luisi. Sturnira (Phyllostomidae, Stenodermatinae) is the most diverse genus in its family, with 22 described species and one undescribed species [90]. Until recently, the taxonomy of the genus was poorly understood and primarily based on morphological characteristics. Early reports of different Sturnira species, including $S$. luisi, were confused with 
Table 5. Overview of studied bat flies. Bat fly species sampled from Chucantí during this study, with the prevalence of Laboulbeniales infections and indication of parasite species.

\begin{tabular}{|c|c|c|c|c|c|}
\hline Bat fly species & Bat host & $\begin{array}{l}\text { No. } \\
\text { sampled }\end{array}$ & $\begin{array}{l}\text { No. } \\
\text { infected }\end{array}$ & $\begin{array}{l}\% \\
\text { infected }\end{array}$ & Laboulbeniales species \\
\hline$\overline{\text { Anatrichobius scorzai }}$ & All & 3 & 0 & & \\
\hline Aspidoptera phyllostomatis & All & 9 & 0 & & \\
\hline Basilia anceps & Myotis riparius & 1 & 0 & & \\
\hline Megistopoda aranea & Artibeus jamaicensis & 12 & 3 & 25.00 & $\begin{array}{l}\text { (1) Gloeandromyces nycteribiidarum } \\
\text { (1) Gloeandromyces streblae } \\
\text { (1) Nycteromyces streblidinus }\end{array}$ \\
\hline Megistopoda aranea & Other bat host species & 9 & 0 & & \\
\hline Megistopoda proxima & Sturnira luisi & 1 & 0 & & \\
\hline Nycterophilia parnelli & Carollia perspicillata & 1 & 0 & & \\
\hline Paratrichobius longicrus & Artibeus jamaicensis & 1 & 0 & & \\
\hline Speiseria ambigua & Carollia perspicillata & 42 & 1 & 2.38 & Gloeandromyces sp. \\
\hline Speiseria ambigua & Other bat host species & 3 & 0 & & \\
\hline Strebla guajiro & Carollia perspicillata & 22 & 0 & & \\
\hline Trichobius anducei & Carollia perspicillata & 6 & 0 & & \\
\hline Trichobius dugesioides & Trachops cirrhosus & 19 & 5 & 26.32 & $\begin{array}{l}\text { (1) Gloeandromyces pageanus } \\
\text { (4) Gloeandromyces streblae }\end{array}$ \\
\hline Trichobius dugesioides & Myotis riparius & 1 & 0 & & \\
\hline Trichobius joblingi & Carollia brevicauda & 6 & 1 & 16.67 & $\begin{array}{l}\text { Gloeandromyces sp. nov. } \\
1+\text { Nycteromyces streblidinus }\end{array}$ \\
\hline Trichobius joblingi & Carollia perspicillata & 244 & 20 & 8.20 & $\begin{array}{l}\text { (2) Gloeandromyces sp. indet. } \\
\text { (1) Gloeandromyces sp. } \\
\text { indet. + Nycteromyces streblidinus } \\
\text { (2) Gloeandromyces } \text { sp. nov. } 1 \\
\text { (1) Gloeandromyces sp. nov. } \\
\text { 1 + Gloeandromyces streblae } \\
\text { (2) Gloeandromyces sp. nov. } 3 \\
\text { (1) Gloeandromyces } \text { sp. nov. } 2 \\
\text { (4) Gloeandromyces streblae } \\
\text { (3) Gloeandromyces } \\
\text { streblae }+ \text { Nycteromyces streblidinus } \\
\text { (1) Laboulbeniales sp. indet. } \\
\text { (3) Nycteromyces streblidinus }\end{array}$ \\
\hline Trichobius joblingi & Other bat host species & 6 & 0 & & \\
\hline Trichobius johnsonae & Pteronotus gymnonotus & 1 & 0 & & \\
\hline Trichobius parasiticus & Desmodus rotundus & 1 & 0 & & \\
\hline Trichobius yunkeri & Pteronotus parnellii & 49 & 0 & & \\
\hline Total & & 437 & 30 & 6.86 & \\
\hline
\end{tabular}

S. lilium [88]. However, at present 21 monophyletic species-level clades have been identified based on molecular characters from 5 gene regions [89,90]. Sturnira luisi is considered abundant at high elevations [43, as $S$. ludovici] and occurs throughout Costa Rica to Ecuador and northwest Peru [79], although the presence of this species in Colombia has not been verified. Sturnira luisi has been found at Cerro Mali $(1433 \mathrm{~m})$ and Tacarcuna Village in Darién at $594 \mathrm{~m}$, as well as Cerro Punta, Chiriqui (1402$1615 \mathrm{~m}$ ), and upper Rio Changena, Bocas del Toro (732$1524 \mathrm{~m})$.

Both P. helleri [77] and Myotis riparius [43] are uncommon species, which is in accordance with our findings. Previously, M. riparius bats have been found in Darién in Boca de Rio Paya and Tacarcuna Village at $594 \mathrm{~m}$, as well as Armila (San Bias), and Cerro Azul
(Panama) at $609 \mathrm{~m}$ [43, as $M$. simus riparius]. Both $M$. schmidtorum and L. obscura are rare species. Micronycteris schmidtorum is found in deciduous forests, and has only been recorded in Panama at Guanico, Los Santos province [43]. Our capture of M. schmidtorum is a new report for Darién. We found L. obscura at $681 \mathrm{~m}$ in the tropical broadleaf forest, which is different from previous findings where L. obscura was found in evergreen forests and fruit groves, in Tacarcuna Village at $975 \mathrm{~m}$ (Darién), Armila (San Blas), Almirante, and upper Rio Changena at $732 \mathrm{~m}$ (Bocas del Toro).

Following the determination keys by Handley Jr. [44] and Timm and LaVal [87], we identified three species of Artibeus on site, A. intermedius, A. jamaicensis, and A. lituratus. However, discussion exists about the validity of $A$. intermedius. Morphological studies show differences 

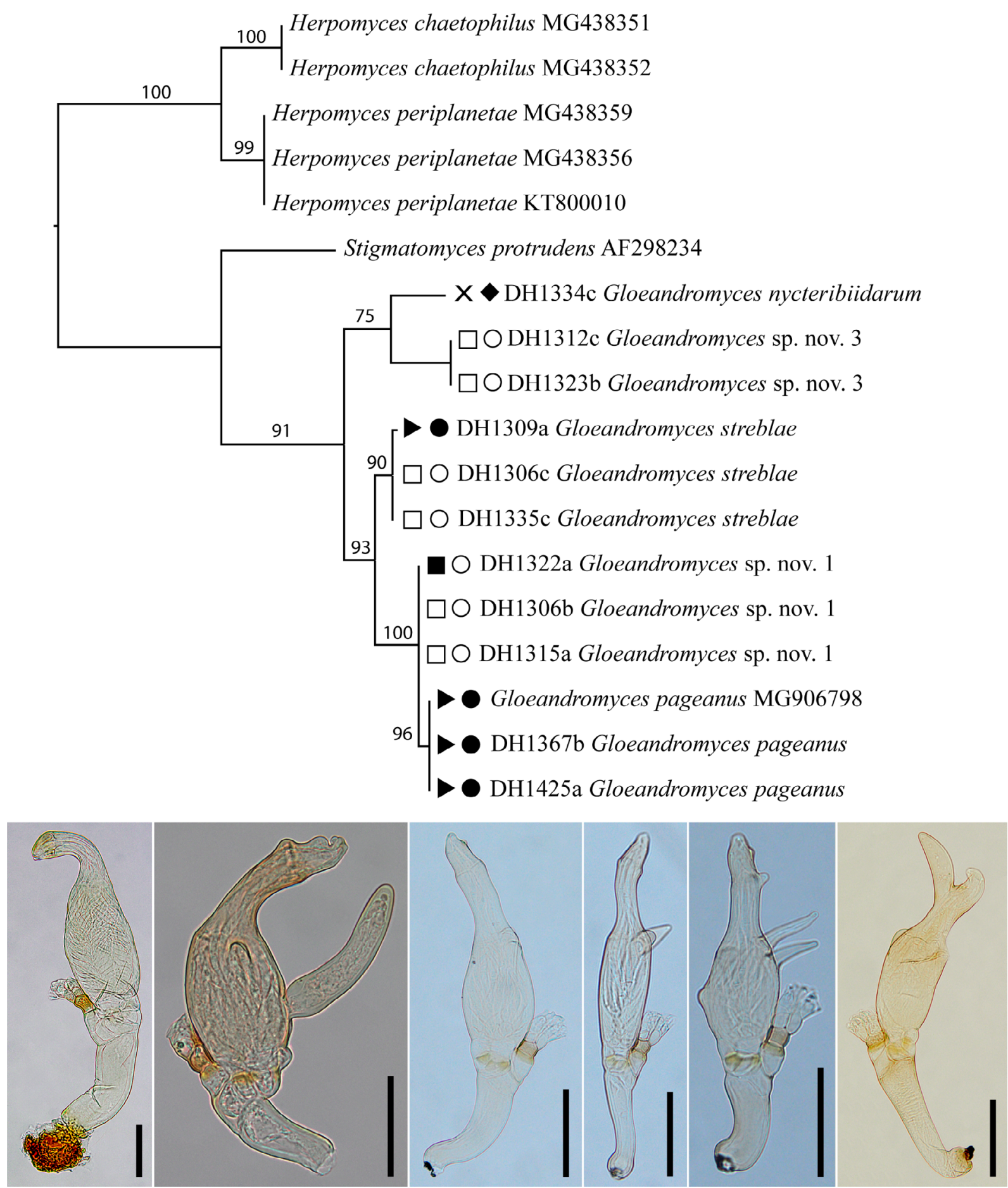

Figure 5. Phylogeny of the genus Gloeandromyces, with Herpomyces species as outgroup taxa, reconstructed from the LSU dataset. The topology is the result of maximum likelihood inference performed using Paup. For each node, the bootstrap support value (if $>70$ ) is presented above the branch leading to that node. Bat hosts and bat fly hosts are indicated left of each isolate: $\square$ Carollia perspicillata, C. brevicauda, $\times$ Artibeus jamaicensis, - Trachops cirrhosus; - Trichobius dugesioides, ○ T. joblingi, $\$ Megistopoda aranea. Photos of thalli from left to right: Gloeandromyces nycteribiidarum, G. sp. nov. 3, G. streblae, G. sp. nov. 1, G. pageanus, and G. sp. nov. 2 (not present in phylogenetic reconstruction). Scale bars $=50 \mu \mathrm{m}$.

in skull morphology between larger-sized A. lituratus and the smaller $A$. intermedius [60], but molecular phylogenetic studies based on mitochondrial genes [46,76] leave the taxonomy of these two taxa unresolved. In the phylogeny by Guerrero et al. [38], based on mitochondrial
DNA, a well-supported clade of A. lituratus from South America also contained $A$. intermedius isolates from Costa Rica, Honduras, Mexico, and Panama. The authors concluded that $A$. intermedius should be treated as a junior synonym of $A$. lituratus [sensu 5,79$]$. 
Table 6. All species of bat flies reported in Panama to date. Bat hosts reported in Darién are provided. Bat flies in bold are new reports for Darién. One of these, Trichobius anducei, also represents a new country record.

\begin{tabular}{|c|c|c|}
\hline Bat fly species & Bat hosts in Darién & Reference(s) \\
\hline \multicolumn{3}{|l|}{ NYCTERIBIIDAE } \\
\hline Basilia anceps & Myotis riparius & {$[39$, this study] } \\
\hline Basilia dunni & Myotis albescens & {$[39]$} \\
\hline Basilia ferruginea & & {$[39]$} \\
\hline Basilia handleyi & & {$[39]$} \\
\hline Basilia myotis & Myotis nigricans & [39] \\
\hline Basilia tiptoni & & {$[39]$} \\
\hline Basilia wenzeli & & {$[39]$} \\
\hline \multicolumn{3}{|l|}{ STREBLIDAE } \\
\hline Anastrebla mattadeni & Anoura cultrata & {$[94]$} \\
\hline Anastrebla modestini & & {$[94]$} \\
\hline Anastrebla nycteridis & Lonchophylla robusta & {$[94]$} \\
\hline Anatrichobius scorzai & Myotis riparius & [94, this study] \\
\hline \multirow[t]{4}{*}{ Aspidoptera phyllostomatis } & Artibeus jamaicensis & {$[27,94$, this study $]$} \\
\hline & Artibeus lituratus $^{*}$ & [94, this study] \\
\hline & Phyllostomus hastatus ${ }^{*}$ & {$[27]$} \\
\hline & Vampyressa nymphaea* $^{*}$ & {$[94]$} \\
\hline Aspidoptera delatorrei & Sturnira lilium & {$[27,94]$} \\
\hline Eldunnia breviceps & & {$[94]$} \\
\hline Exastinion clovisi & & {$[94]$} \\
\hline Joblingia schmidti & & {$[94]$} \\
\hline Mastoptera guimaraesi & Phyllostomus hastatus & {$[27,94]$} \\
\hline Mastoptera minuta & Lophostoma silvicolum & {$[94]$} \\
\hline \multirow[t]{4}{*}{ Megistopoda aranea } & Artibeus jamaicensis & {$[27,94$, this study $]$} \\
\hline & Artibeus lituratus $^{*}$ & {$[94$, this study $]$} \\
\hline & Phyllostomus discolor ${ }^{*}$ & {$[94]$} \\
\hline & Pteronotus parnellii* & this study \\
\hline \multirow[t]{2}{*}{ Megistopoda proxima } & Sturnira lilium & {$[94]$} \\
\hline & Sturnira luisi & this study \\
\hline Megistopoda theodori & Sturnira ludovici & {$[94]$} \\
\hline \multirow[t]{3}{*}{ Metelasmus pseudopterus } & Artibeus jamaicensis & {$[27,94]$} \\
\hline & Carollia perspicillata ${ }^{*}$ & {$[94]$} \\
\hline & Vampyressa nymphaea* & {$[94]$} \\
\hline \multirow[t]{2}{*}{ Neotrichobius stenopterus } & Dermanura phaeotis & {$[27]$} \\
\hline & Vampyressa pusilla ${ }^{*}$ & [94] \\
\hline Noctiliostrebla maai & Noctilio albiventris & {$[94]$} \\
\hline Noctiliostrebla traubi & Noctilio leporinus & {$[94]$} \\
\hline Nycterophilia fairchildi & & {$[94]$} \\
\hline Nycterophilia natali & & {$[94]$} \\
\hline Nycterophilia parnelli & Pteronotus parnellii & {$[94$, this study] } \\
\hline Paradyschiria lineata & & {$[94]$} \\
\hline Paradyschiria parvuloides & Noctilio albiventris & {$[94]$} \\
\hline Parastrebla handleyi & & {$[94]$} \\
\hline Paratrichobius dunni & Uroderma bilobatum & {$[27,94]$} \\
\hline Paratrichobius longicrus & Artibeus jamaicensis $^{*}$ & [94, this study] \\
\hline Paratrichobius lowei & Dermanura watsoni & {$[94]$} \\
\hline Paratrichobius salvini & Chiroderma salvini & {$[27,94]$} \\
\hline Paratrichobius sanchezi & Enchisthenes hartii & {$[94]$} \\
\hline Paratrichobius sp. (longicrus complex) & Platyrrhinus vittatus & {$[94]$} \\
\hline Pseudostrebla greenwelli & & {$[94]$} \\
\hline
\end{tabular}


Table6. (continued).

\begin{tabular}{|c|c|c|}
\hline Bat fly species & Bat hosts in Darién & Reference(s) \\
\hline Pseudostrebla ribeiroi & & {$[94]$} \\
\hline \multirow[t]{3}{*}{ Speiseria ambigua } & Carollia castanea & {$[27,94]$} \\
\hline & Carollia perspicillata & {$[27,94$, this study $]$} \\
\hline & Trachops cirrhosus ${ }^{*}$ & this study \\
\hline Strebla altmani & Macrophyllum macrophyllum & {$[94]$} \\
\hline Strebla alvarezi & & {$[94]$} \\
\hline \multirow[t]{2}{*}{ Strebla guajiro } & Carollia castanea & {$[27,94]$} \\
\hline & Carollia perspicillata & {$[27,94$, this study $]$} \\
\hline Strebla christinae & & {$[94]$} \\
\hline Strebla diaemi & & {$[94]$} \\
\hline Strebla galindoi & & {$[94]$} \\
\hline Strebla hertigi & Phyllostomus discolor & {$[94]$} \\
\hline Strebla hoogstraali & & {$[94]$} \\
\hline Strebla kohlsi & Lophostoma silvicolum & {$[94]$} \\
\hline Strebla mirabilis & Phyllostomus hastatus & {$[27,94]$} \\
\hline Strebla wiedemanni & Desmodus rotundus & {$[94]$} \\
\hline Trichobioides perspicillatus & Sturnira lilium ${ }^{*}$ & {$[94]$} \\
\hline Trichobius anducei & Carollia perspicillata & this study \\
\hline Trichobius bequarti & & {$[94]$} \\
\hline Trichobius brennani & Sturnira ludovici & {$[94]$} \\
\hline Trichobius costalimai & Phyllostomus discolor & {$[94]$} \\
\hline Trichobius dugesii & Glossophaga soricina & {$[94]$} \\
\hline \multirow[t]{3}{*}{ Trichobius dugesioides } & Carollia perspicillata & {$[94]$} \\
\hline & ?Tonatia sp. & {$[94]$} \\
\hline & Trachops cirrhosus & this study \\
\hline Trichobius dunni & Molossus bondae & {$[94]$} \\
\hline Trichobius galei & & {$[94]$} \\
\hline \multirow[t]{6}{*}{ Trichobius joblingi } & Carollia brevicauda & this study \\
\hline & Carollia castanea & {$[27,94]$} \\
\hline & Carollia perspicillata & {$[27,94$, this study $]$} \\
\hline & Carollia subrufa & {$[94]$} \\
\hline & Carollia sp. & {$[94]$} \\
\hline & Micronycteris schmidtorum ${ }^{*}$ & this study \\
\hline Trichobius johnsonae & Pteronotus gymnonotus & {$[94$, this study] } \\
\hline Trichobius keenani & & {$[94]$} \\
\hline Trichobius lionycteridis & & {$[94]$} \\
\hline Trichobius lonchophyllae & Lonchophylla robusta & {$[94]$} \\
\hline Trichobius longipes & Phyllostomus hastatus & {$[27,94]$} \\
\hline Trichobius macrophylli & & {$[94]$} \\
\hline Trichobius mendezi & & {$[94]$} \\
\hline Trichobius parasiticus & Desmodus rotundus & {$[94$, this study] } \\
\hline Trichobius sparsus & Phyllostomus hastatus ${ }^{*}$ & {$[27,94]$} \\
\hline Trichobius uniformis & & {$[94]$} \\
\hline Trichobius urodermae & Uroderma bilobatum & {$[94]$} \\
\hline Trichobius vampyropis & & {$[94]$} \\
\hline Trichobius yunkeri & Pteronotus parnellii & {$[94$, this study] } \\
\hline
\end{tabular}

${ }^{*}=$ non-primary association [sensu 15,94]. Bat names are presented without subspecies designation and have been updated following Simmons [79]. 

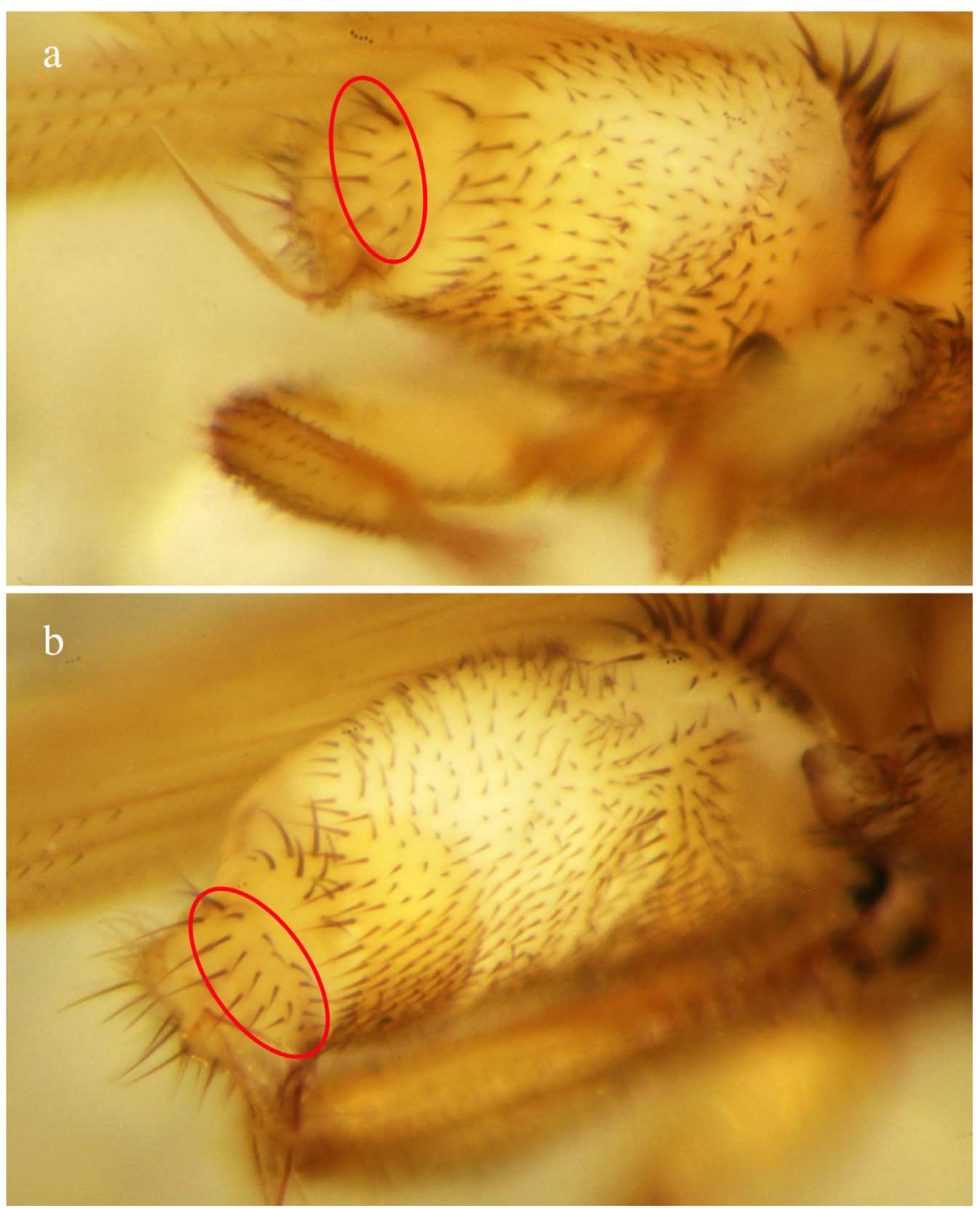

Figure 6. The abdomen of two male bat fly specimens, showing and comparing the typical setation of the 9 th tergite in two Trichobius species [sensu 36]. (a) Trichobius anducei with 9-11 setae. (b) Trichobius dugesioides with 17-20 setae on the 9th tergite.

This survey shows there are many species taking advantage of the forest types of Chucantí, at all three elevations and vegetation types. We mostly captured phyllostomid bats, which is not surprising given the fact that mistnets are most effective in targeting this family [59]. High-flying bats are generally underrepresented using low residing capture methods such as mistnets and harp traps [20,25]. A return to Chucantí with additional equipment (ultrasonic bat detectors/ triple-high systems) would complete our current picture of bat species.

\section{What can bats tell us about forest regeneration?}

Bats play an important role in forest restoration and are indicators of forest health. An increased prevalence of bats in regions impacted by deforestation indicates regenerative secondary succession $[8,64]$, that is, native flora returning to a disturbed area. This occurrence is coupled with the notion that the regenerative success is supportive of speciose bat populations, which occupy various niches [50]. In turn, bats permit swift forest regeneration, providing key ecological roles including 
habitat building, seed dispersal and pest control [51,54,57]. In Panama, deforestation and disturbance is an ongoing issue [68].

In 1997, three quarters of Darién was forested [68]. However, prominent tree stands, including the commercial cativo (Prioria copaifera) and the less commercially suitable cuipo (Cavanillesia platanifolia), continued to be felled for timber or removed in slash-and-burn operations for agricultural land to support jobs and livelihoods of locals $[28,68]$. The area of forest dominated by cativo has decreased by half between 1987 and 1999 [1,47]. The majority of deforestation of both cativo and cuipo is for agricultural purposes alone [68]; between 1987 and 1997 edges of existing cultivars had expanded into forest and increased agricultural area by up to $75 \%$. This has posed a considerable threat to Darién forests and, subsequently, to their bat populations. However, deforestation prevention and conservation efforts are being supported by government, private organizations, and private landowners. The Food and Agriculture Organization of the United Nations (FAO) reports that $90.4 \%$ of Panama's forests are privately owned [22], the $6 \mathrm{~km}^{2}$ Chucantí Nature Reserve being a prime example [10,48]. Efforts in Chucantí have aimed to reverse habitat degradation and recover the original ecosystem. These efforts have included removing agricultural farm animals and allowing forests to encroach on land, which had previously been used for cattle ranching [48].

The ability to fly allows bats to adapt to changes in their environment and among landscapes [52], while differences in morphology, and niche and dietary preferences allow individual species to respond differently to environmental stressors [24,50,63]. Frugivorous species, such as Carollia, benefit in forests of secondary succession, granted their roosting or foraging areas are not subject to change [49]. Once abundant, Carollia and other frugivorous species can speed forest regeneration, as they readily disperse seeds [57]. The abundance of Carollia and Artibeus in our study is supportive of previous findings, suggesting the abundance of neotropical frugivore species can increase in response to regeneration of tropical forests [63]. It is also likely that they contribute to the occurrence of early successional vegetation [67]. Importantly, the abundance of these two species highlights the regenerative success of Chucantí.

Bat species composition and abundance in Chucantí is relatively comparable to that of undisturbed forests in other parts of Panama [77], which most likely helps regenerate the forest. Although these secondary forests can harbor many bat species, host assemblages will likely still differ from primary forests [4]. This study provides insight into the current successful regenerative efforts in Chucantí, with potential trophic cascades affecting other inhabiting species. Through continued management [sensu 91], adaptable bat species capable of providing ecosystem services $[51,54,67]$ can be attracted to these regenerating forests and speed up this secondary succession, further promoting the rehabilitation of the Chucantí Nature Reserve.

\section{Conclusions}

This study shows that the relatively unexplored Darién province in Panama holds much to discover. During 68 mistnet hours, we captured bats representing 17 different species, of which Micronycteris schmidtorum was previously unreported in Darién and Platyrrhinus dorsalis represents the westernmost report for this species thus far. We screened captured bats for presence of ectoparasitic bat flies, which we in turn screened for presence of ectoparasitic Laboulbeniales fungi. The bat fly Trichobius anducei was sampled for the first time in Panama and five bat fly species are new reports for Darién. Finally, we found 7 species of Laboulbeniales on 30 bat flies, of which 1 species represents a new country record and 3 are undescribed. Considering the small sample size, we are confident that many more new discoveries will be made in this unique part of Panama.

Acknowledgements. We would like to thank Guido Berguido (Asociación Adopta el Bosque Panamá), Michelle Nowak, and Rachel Page (Smithsonian Tropical Research Institute, Gamboa, Panama) for helping with logistical aspects of this expedition to Chucantí; W. Owen McMillan (Smithsonian Tropical Research Institute, Gamboa, Panama) and Edilma Gomez (Molecular Multi-User's Lab, Amador Causeway, Naos Island, Panama) for facilitating molecular work locally; and E. Allen Herre (Smithsonian Tropical Research Institute, Gamboa, Panama) for use of his lab space and equipment. Our appreciation goes to the staff at the field station, especially Jacobo Ortega, Expedito Sanjur, and Edilma Zambrano. A huge shout-out to José and Alice Ramirez Zambrano, son and daughter of Edilma, for their interest in our work and assistance in and around the field station. Many thanks go to Rafael Samudio for critically reviewing the manuscript. DH received funding for this work from the following sources: Harvard University Herbaria (Fernald Fund), David Rockefeller Center for Latin American Studies (Summer Research Travel Grant), Smithsonian Tropical Research Institute (Short-Term Research Fellowship), and Mycological Society of America (Graduate Fellowship, Robert W. Lichtwardt Student Research Award).

\section{Conflict of interest}

The authors declare that they have no conflicts of interest in relation to thisarticle.

\section{Supplementary Material}

Table S1. List of bat species captured at Chucantí Nature Reserve in Darién province, Panama. For each species, number of captured individuals (N), average forearm length (in $\mathrm{mm}$ ), and average body mass (in g) are provided. Recaptures are not included in sample sizes or averages. Photos: Danny Haelewaters and Annabel Dorrestein. The Supplementary Material is available at https://www.parasite-journal.org/10.1051/ parasite/2018017/olm. 


\section{References}

1. M. 1999. Panamá Informe Ambiental. Autoridad Nacional del Ambiente, Panamá.

2. Angehr G, Christian, D. 2000. Distributional records from the highlands of the Serranía de Majé, an isolated mountain range in eastern Panama. Bulletin-British Ornithologists Club 120, 173-178.

3. Araúz J. 2002. Los murciélagos del sendero panamá, parque nacional altos de Campana, Panamá. Tecnociencia, 4, 35-48.

4. Barlow J, Gardner TA, Araujo IS, Ávila-Pires TC, Bonaldo AB, Costa JE, Esposito MC, Ferreira LV, Hawes J, Hernandez MIM, Hoogmoed MS, Leite RN, Lo-Man-Hung NF, Malcolm JR, Martins MB, Mestre LAM, MirandaSantos R, Nunes-Gutjahr AL, Overal WL, Parry L, Peters SL, Ribeiro-Junior MA, da Silva MNF, da Silva Motta C, Peres CA. 2007. Quantifying the biodiversity value of tropical primary, secondary, and plantation forests. Proceedings of the National Academy of Sciences, 104, 18555-18560.

5. Barquez RM, Perez S, Miller B, Diaz M. 2015. Artibeus lituratus. The IUCN red list of threatened species 2015 . Accessed October 6, 2017.

6. Benjamin RK. 1971. Introduction and supplement to Roland Thaxter's contribution towards a monograph of the Laboulbeniaceae. Bibliotheca Mycologica, 30, 1-155.

7. Blackwell M. 1980. Incidence, host specificity, distribution, and morphological variation in Arthrorhynchus nycteribiae and A. eucampsipodae (Laboulbeniomycetes). Mycologia, $72,143-158$.

8. Castro-Luna AA, Sosa VJ, Castillo-Campos G. 2007. Bat diversity and abundance associated with the degree of secondary succession in a tropical forest mosaic in southeastern Mexico. Animal Conservation, 10, 219-228.

9. Churchill S. 2008. Australian Bats, Sydney, Allen and Unwin.

10. Colegrove L. 2017. Land purchase in Panama helps protect a "sky island" of cloud forest for threatened amphibians. Accessed October 4, 2017. https://www.rainforesttrust. org/news/strategic-land-purchase-in-panama-protects-asky-island-of-cloud-forest-for-threatened-amphibians

11. Darriba D, Taboada GL, Doallo R, Posada D. 2012. jModelTest 2: more models, new heuristics and parallel computing. Nature methods, $9,772$.

12. De Kesel A, Haelewaters D. 2014. Laboulbenia slackensis and L. littoralis sp. nov. (Ascomycota, Laboulbeniales), two sibling species as a result of ecological speciation. Mycologia, 106, 407-414.

13. Dick CW. 2007. High host specificity of obligate ectoparasites. Ecological Entomology, 32, 446-450.

14. Dick CW. 2013. Review of the bat flies of Honduras, Central America (Diptera: Streblidae). Journal of Parasitology Research, 2013, article ID 437696.

15. Dick CW, Gettinger D. 2005. A faunal survey of streblid flies (Diptera: Streblidae) associated with bats in Paraguay. Journal of Parasitology, 91, 1015-1024.

16. Dick CW, Patterson BD. 2006. Bat flies: obligate ectoparasites of bats, in Micromammals and macroparasites: from evolutionary ecology to management. Morand, S., Krasnov, B. R. \& Poulin, R, Editors. Springer: Tokyo. p. 179-194.

17. Dinerstein E, Olson DM, Graham DJ, Webster AL, Primm SA, Bookbinder MP, Ledec G. 1995. A conservation assessment of the terrestrial ecoregions of Latin America and the Caribbean. Washington, DC: World Wildlife FundUS. The World Bank.

18. Dittmar K, Porter ML, Murray S, Whiting MF. 2006. Molecular phylogenetic analysis of nycteribiid and streblid bat flies (Diptera: Brachycera, Calyptratae): implications for host associations and phylogeographic origins. Molecular Phylogenetics and Evolution, 38, 155-170.

19. Dormann CF, Gruber B, Fründ J. 2008. Introducing the bipartite package: analysing ecological networks. R News, 8 , 8-11.

20. Duffy AM, Lumsden LF, Caddle CR, Chick RR, Newell GR. 2000. The efficacy of Anabat ultrasonic detectors and harp traps for surveying microchiropterans in south-eastern Australia. Acta Chiropterologica, 2, 127-144.

21. Edgar RC. 2004. MUSCLE: multiple sequence alignment with high accuracy and high throughput. Nucleic Acids Research, 32, 1792-1797.

22. FAO. 2005. Forest Resources Assessment 2005-Global Tables. Ownership of forest and other wooded land 2000. Accessed October 25, 2017. http://www.fao.org/forestry/ $32034 /$ en

23. FAO. 2015. Global Forest Resources Assessment Rome: UN Food and Agriculture Organization.

24. Fenton MB, Acharya L, Audet D, Hickey MBC, Merriman C, Obrist MK, Syme DM, Adkins B. 1992. Phyllostomid bats (Chiroptera: Phyllostomidae) as indicators of habitat disruption in the Neotropics. Biotropica, 24, 440-446.

25. Flaquer C, Torre I, Arrizabalaga A. 2007. Comparison of sampling methods for inventory of bat communities. Journal of Mammalogy, 88, 526-533.

26. Freeman PW. 1988. Frugivorous and animalivorous bats (Microchiroptera): dental and cranial adaptations. Biological Journal of the Linnean Society, 33, 249-272.

27. González DP, Santos AM, Miranda JR. 2004. Streblidae (Diptera: Pupipara) ectoparásitos de murciélagos, en las tierras bajas del Parque Nacional Darien, provincia de Darién, Panamá. Tecnociencias, 6, 1-12.

28. Grauel WT. 2004. Ecology and management of wetland forests dominated by Prioria copaifera in Darien, Panama. Doctoral dissertation, University of Florida, Gainesville, Florida.

29. Guerrero R. 1993. Catalogo de los Streblidae (Diptera: Pupipara) parasitos de murcielagos (Mammalia: Chiroptera) del Nuevo Mundo I. Clave para los géneros y Nycterophiliinae. Acta Biologica Venezuelica, 14, 61-75.

30. Guerrero R. 1994a. Catalogo de los Streblidae (Diptera: Pupipara) parasitos de murcielagos (Mammalia: Chiroptera) del Nuevo Mundo II. Los grupos: pallidus, caecus, major, uniformis y longipes del género Trichobius (Gervais, 1844). Acta Biologica Venezuelica, 15, 1-18.

31. Guerrero R. 1994b. Catalogo de los Streblidae (Diptera: Pupipara) parasitos de murcielagos (Mammalia: Chiroptera) del Nuevo Mundo IV. Trichobiinae con alas desarrolladas. Boletín de Entomología Venezolana, 9, 161-192.

32. Guerrero R. 1995a. Catalogo de los Streblidae (Diptera: Pupipara) parasitos de murcielagos (Mammalia: Chiroptera) del Nuevo Mundo III. Los grupos: dugesii, dunni y phyllostomae del género Trichobius (Gervais, 1844). Acta Biologica Venezuelica, 15, 1-27.

33. Guerrero R. 1995b. Catalogo de los Streblidae (Diptera: Pupipara) parasitos de murcielagos (Mammalia: Chiroptera) del Nuevo Mundo V. Trichobiinae con alas reducidas o ausentes y miscelaneos. Boletín de Entomología Venezolana, 10, 135-160.

34. Guerrero R. 1996. Catálogo de los Streblidae (Diptera: Pupipara) parásitos de murciélagos (Mammalia: Chiroptera) del Nuevo Mundo VI. Streblinae. Acta Biologica Venezuelica, 16, 1-26.

35. Guerrero R. 1997. Catálogo de los Streblidae (Diptera: Pupipara) parásitos de murciélagos (Mammalia: Chiroptera) del Nuevo Mundo VII. Lista de especies, hospedadores y países. Acta Biologica Venezuelica, 17, 9-24. 
36. Guerrero R. 1998a. Notes on Neotropical batflies (Diptera, Streblidae). I. The genus Trichobius, with description of two new species and one new subspecies from Venezuela. Acta Parasitologica, 43, 86-93.

37. Guerrero R. 1998b. Notes on Neotropical bat flies (Diptera: Streblidae): II. Review of the genus Xenotrichobius. Acta Parasitologica, 43, 142-147.

38. Guerrero JA, Ortega J, Gonzalez D, Maldonado JE, Lorenzo C, Espinoza E. 2008. Molecular phylogenetics and taxonomy of the fruit-eating bats of the genus Artibeus (Chiroptera: Phyllostomidae). Avances en el Estudio de los Mamiferos de México. Publicaciones Especiales, 2, 125-146.

39. Guimarães LR. 1966. Nycteribiid batflies from Panama (Diptera: Nycteribiidae), in Ectoparasites of Panama. Wenzel RL, Tipton VJ, Editors. Field Museum of Natural History: Chicago. p. 393-404.

40. Haelewaters D, Pfliegler WP, Gorczak M, Pfister DH. In review. Birth of an order: comprehensive phylogenetic study excludes Herpomyces (Fungi, Laboulbeniomycetes) from Laboulbeniales. Molecular Phylogenetics and Evolution.

41. Haelewaters D, Pfliegler WP, Szentivanyi T, Foldvari M, Sandor AD, Barti L, Camacho JJ, Gort G, Estok P, Hiller T, Dick CW, Pfister DH. 2017a. Parasites of parasites of bats: Laboulbeniales (Fungi: Ascomycota) on bat flies (Diptera: Nycteribiidae) in central Europe. Parasites \& Vectors, 10, 96.

42. Haelewaters D, Verhaeghen SJC, Rios Gonzalez TA, Bernal Vega JA, Villarreal Saucedo RV. 2017b. New and interesting Laboulbeniales from Panama and neighboring areas. Nova Hedwigia, 105, 267-299.

43. Handley Jr. CO. 1966. Checklist of the mammals of Panama, in Ectoparasites of Panama. Wenzel RL, Tipton VJ, Editors. Field Museum of Natural History: Chicago. p. 753-795.

44. Handley Jr. CO. 1981. Key to the bats of the lowlands of Panama. Washington DC: National Museum of Natural History.

45. Holdridge LR, Grenke WC, Hatheway WH, Liang T, Tosi JA. 1971. Forest environments in tropical life zones: a pilot study. Forest environments in tropical life zones: a pilot study. Oxford, UK: Pergamon Press.

46. Hoofer SR, Solari S, Larsen PA, Bradley RD, Baker RJ. 2008. Phylogenetics of the fruit-eating bats (Phyllostomidae: Artibeina) inferred from mitochondrial DNA sequences. Occasional Papers, The Museum Texas Tech University, 277, 1-15.

47. INRENARE. 1987. Situación General de los Bosques de Cativo y su Utilización. Instituton Nacional de Recursos Naturales Renovables, Panama.

48. International Conservation Fund of Canada (ICFC). 2017. Land acquisition of Cerro Chucantí nature reserve, Panama. Accessed October 25, 2017. http://icfcanada.org/ourprojects/projects/panama-cerro-chucanti

49. Jones KE, Barlow KE, Vaughan N, Rodríguez-Durán A, Gannon MR. 2001. Short-term impacts of extreme environmental disturbance on the bats of Puerto Rico. Animal Conservation Forum, 4, 59-66.

50. Jones G, Jacobs DS, Kunz TH, Willig MR, Racey PA. 2009. Carpe noctem: the importance of bats as bioindicators. Endangered Species Research, 8, 93-115.

51. Kalka MB, Smith AR, Kalko EK. 2008. Bats limit arthropods and herbivory in a tropical forest. Science, $320,71-71$.

52. Kalko EKV, Handley CO, Handley D. 1996. Organization, diversity, and long-term dynamics of a neotropical bat community, in Long-term studies of vertebrate communities. Cody ML, Smallwood JA, Editors. Academic Press: San Diego. p. 503-553.
53. Kunz TH, Lumsden LF. 2003. Ecology of cavity and foliage roosting bats, in Bat ecology. Kunz TH, Fenton MB, Editors. University of Chicago Press: Chicago. p. 3-89.

54. Kunz TH, Braun De Torrez E, Bauer D, Lobova T, Fleming TH. 2011. Ecosystem services provided by bats. Annals of the New York Academy of Sciences, 1223, 1-38.

55. Laurance WF. 2008. Adopt a Forest. Biotropica, 40, 3-6.

56. Linhares AX, Komeno CA. 2000. Trichobius joblingi, Aspidoptera falcata, and Megistopoda proxima (Diptera: Streblidae) parasitic on Carollia perspicillata and Sturnira lillium (Chiroptera: Phyllostomidae) in southeastern Brazil: Sex ratios, seasonality, host site preference, and effect of parasitism on the host. Journal of Parasitology, 86, 167-170.

57. Lopez JE, Vaughan C. 2004. Observations on the role of frugivorous bats as seed dispersers in Costa Rican secondary humid forests. Acta Chiropterologica, 6, 111-119.

58. Lourenço EC, Almeida JC, Famadas KM. 2016. Richness of ectoparasitic flies (Diptera: Streblidae) of bats (Chiroptera) - a systematic review and meta-analysis of studies in Brazil. Parasitology Research, 115, 4379-4388.

59. Macswiney MC, Clarke FM, Racey PA. 2008. What you see is not what you get: the role of ultrasonic detectors in increasing inventory completeness in Neotropical bat assemblages. Journal of Applied Ecology, 45, 1364-1371.

60. Marchán-Rivadeneira MR, Larsen PA, Phillips CJ, Strauss RE, Baker RJ. 2012. On the association between environmental gradients and skull size variation in the great fruiteating bat, Artibeus lituratus (Chiroptera: Phyllostomidae). Biological Journal of the Linnean Society, 105, 623-634.

61. Martínez-Garza C, Howe HF. 2003. Restoring tropical diversity: beating the time tax on species loss. Journal of Applied Ecology, 40, 423-429.

62. Mclellan LJ. 1984. A morphometric analysis of Carollia (Chiroptera, Phyllostomidae). American Museum Novitates, 2791, 1-35.

63. Meyer CFJ, Kalko EKV. 2008. Assemblage-level responses of phyllostomid bats to tropical forest fragmentation: landbridge islands as a model system. Journal of Biogeography, $35,1711-1726$.

64. Meyer CF, Struebig MJ, Willig MR. 2016. Responses of tropical bats to habitat fragmentation, logging, and deforestation, in Bats in the anthropocene: Conservation of bats in a changing world. Voigt CC, Kingston T, Editors. Springer International Publishing: Cambridge, Massachusetts. p. 63-103.

65. Miller MA, Pfeiffer W, Schwartz T. 2010. Creating the CIPRES Science Gateway for inference of large phylogenetic trees. Proceedings of the Gateway Computing Environments Workshop (GCE), 14 Nov. 2010, New Orleans, Louisiana. p. 1-8.

66. Miller J, Tschapka M. 2001. The bat flies of La Selva (Diptera: Nycteribiidae, Streblidae). Accessed November 4, 2017. http://www.biologie.uni-ulm.de/bio3/Batfly/index.html

67. Muscarella R, Fleming TH. 2007. The role of frugivorous bats in tropical forest succession. Biological Reviews, 82, $573-590$

68. Nelson GC, Harris V, Stone SW, Barbier EB, Burgess JC. 2001. Deforestation, land use, and property rights: empirical evidence from Darien, Panama. Land Economics, 77, 187-205.

69. Nilsson RH, Kristiansson E, Ryberg M, Hallenberg N, Larsson KH. 2008. Intraspecific ITS variability in the kingdom Fungi as expressed in the international sequence databases and its implications for molecular species identification. Evolutionary Bioinformatics, 4, 193-201.

70. Oksanen J, Blanchet FG, Kindt R, Legendre P, Minchin PR, O'hara RB, Simpson GL, Solymos P, Stevens MHH, 
Wagner H, Oksanen MJ. 2013. Package 'vegan'. Community ecology package, version, 2(9).

71. Ortiz OO, Baldini RM, Berguido G, Croat TB. 2016. New species of Anthurium (Araceae) from Chucantí Nature Reserve, eastern Panama. Phytotaxa, 255, 47-56.

72. Overal WL. 1980. Host-relations of the bat fly Megistopoda aranea (Diptera: Streblidae) in Panama. University of Kansas Science Bulletin, 52, 1-20.

73. Palmeirim JM, Etherdige K. 1985. The influence of manmade trails on foraging by tropical frugivorous bats. Influencia de los senderos hechos por el hombre en el forrajeo de murciélagos frugívoros tropicales. Biotropica, 17, 82-83.

74. Patterson BD, Dick CW, Dittmar K. 2007. Roosting habits of bats affect their parasitism by bat flies (Diptera: Streblidae). Journal of Tropical Ecology, 23, 177-189.

75. R Core Team. 2013. R: a language and environment for statistical computing. Vienna, Austria: R Foundation for Statistical Computing. http://www.R-project.org.

76. Redondo RAF, Brina LPS, Silva RF, Ditchfield AD, Santos FR. 2008. Molecular systematics of the genus Artibeus (Chiroptera: Phyllostomidae). Molecular Phylogenetics and Evolution, 49, 44-58.

77. Samudio Jr. R. 2002. Patterns of diversity and ecology in Panamanian bats at two elevations. Doctoral dissertation, University of Florida, Gainesville, Florida.

78. Samudio Jr. R, Pino JL. 2014. Historia de la Mastozoología en Panamá. Historia de La Mastozoología En Latinoamérica, Las Guayanas Y El Caribe. Editorial Murciélago Blanco y Asociación, Quito y México DF, 329-344.

79. Simmons NB. 2005. Order Chiroptera, in Mammal species of the world: a taxonomic and geographic reference. Third edition. Wilson DE, Reeder DAM, Editors. Johns Hopkins Univ Press: Baltimore, Maryland. p. 312-529.

80. Stamper E. 2012. Host Specificity of Ecuadorian bat flies (Diptera: Streblidae). Honors College Capstone Experience/ Thesis Projects. Paper 358. Accessed October 17, 2017. http://digitalcommons.wku.edu/stu hon theses/358

81. Suzán G, Armién A, Mills JN, Marcé E, Ceballos G, Ávila M, Salazar-Bravo J, Ruedas L, Armién B, Yates TL. 2008. Epidemiological considerations of rodent community composition in fragmented landscapes in Panama. Journal of Mammalogy, 89, 684-690.

82. Svensson MS, Samudio R, Bearder SK, Nekaris K. 2010. Density estimates of Panamanian owl monkeys (Aotus zonalis) in three habitat types. American Journal of Primatology, 72, 187-192.

83. Swofford DL. 1991. PAUP: Phylogenetic Analysis Using Parsimony, Version 3.1 Computer program distributed by the Illinois Natural History Survey, Champaign, Illinois.
84. ter Hofstede HM, Fenton MB, Whitaker Jr JO. 2004. Host and host-site specificity of bat flies (Diptera: Streblidae and Nycteribiidae) on Neotropical bats (Chiroptera). Canadian Journal of Zoology, 82, 616-626.

85. Thaxter R. 1924. Contribution toward a monograph of the Laboulbeniaceae III. Memoirs of the American Academy of Arts and Sciences, 14:309-426, Plates I-XII.

86. Thaxter R. 1931. Contribution toward a monograph of the Laboulbeniaceae V. Memoirs of the American Academy of Arts and Sciences, 16, 1-435, Plates I-LX.

87. Timm RM, LaVal RK. 1998. A field key to the bats of Costa Rica. Occasional Publication Series, University of Kansas Center of Latin American Studies, 22, 1-30.

88. Velazco PM. 2005. Morphological phylogeny of the bat genus Platyrrhinus Saussure, 1860 (Chiroptera: Phyllostomidae) with the description of four new species. Fieldiana: Zoology, n.s., 105, 1-53.

89. Velazco PM, Patterson BD. 2013. Diversification of the yellow-shouldered bats, genus Sturnira (Chiroptera, Phyllostomidae), in the New World tropics. Molecular Phylogenetics and Evolution, 68, 683-698.

90. Velazco PM, Patterson BD. 2014. Two new species of yellow-shouldered bats, genus Sturnira Gray, 1842 (Chiroptera, Phyllostomidae) from Costa Rica, Panama and western Ecuador. ZooKeys, 402, 43-66.

91. Vleut I, Levy-Tacher SI, de Boer WF, Galindo-González J, Vazquez LB. 2013. Tropical secondary forest management influences frugivorous bat composition, abundance and fruit consumption in Chiapas, Mexico. PloS One, 8, e77584.

92. Weir A, Hammond PM. 1997. Laboulbeniales on beetles: Host utilization patterns and species richness of the parasites. Biodiversity and Conservation, 6, 701-719.

93. Wenzel RL. 1976. The streblid batflies of Venezuela (Diptera: Streblidae). Brigham Young University Science Bulletin-Biological Series, 20, 1-177.

94. Wenzel RL, Tipton VJ. 1966. Ectoparasites of Panama. Chicago: Field Museum of Natural History.

95. Wibbelt G, Speck S, Field H. 2009. Methods for assessing diseases in bats, in Ecological and behavioral methods for the study of bats. Kunz THP, Editor. John Hopkins University Press: Baltimore, Maryland. p. 775-794.

96. Wolfe BT, Dent DH, Deago J, Wishnie MH. 2015. Forest regeneration under Tectona grandis and Terminalia amazonia plantation stands managed for biodiversity conservation in western Panama. New Forests, 46, 157165.

97. Woods CL, Dewalt SJ. 2013. The conservation value of secondary forests for vascular epiphytes in Central Panama. Biotropica, 45, 119-127.

Cite this article as: Walker MJ, Dorrestein A, Camacho JJ, Meckler LA, Silas KA, Hiller T, Haelewaters D. 2018. A tripartite survey of hyperparasitic fungi associated with ectoparasitic flies on bats (Mammalia: Chiroptera) in a neotropical cloud forest in Panama. Parasite 25, 19 
O PARASTE

An international open-access, peer-reviewed, online journal publishing high quality papers on all aspects of human and animal parasitology

Reviews, articles and short notes may be submitted. Fields include, but are not limited to: general, medical and veterinary parasitology; morphology, including ultrastructure; parasite systematics, including entomology, acarology, helminthology and protistology, and molecular analyses; molecular biology and biochemistry; immunology of parasitic diseases; host-parasite relationships; ecology and life history of parasites; epidemiology; therapeutics; new diagnostic tools.

All papers in Parasite are published in English. Manuscripts should have a broad interest and must not have been published or submitted elsewhere. No limit is imposed on the length of manuscripts.

Parasite (open-access) continues Parasite (print and online editions, 1994-2012) and Annales de Parasitologie Humaine et Comparée (1923-1993) and is the official journal of the Société Française de Parasitologie. 